\title{
Mutagenesis of all Eight avr Genes in Xanthomonas campestris pv. campestris Had No Detected Effect on Pathogenicity, But One avr Gene Affected Race Specificity
}

\author{
Adriana Castañeda, Joseph D. Reddy, Basma El-Yacoubi, and Dean W. Gabriel \\ Plant Molecular and Cell Biology Program, Plant Pathology Department, University of Florida, Gainesville, FL 32611, U.S.A. \\ Submitted 15 March 2005. Accepted 2 September 2005.
}

\begin{abstract}
Suppression subtractive hybridization (SSH) was used to identify genes present in the systemic crucifer black rot pathogen Xanthomonas campestris pv. campestris $528^{\mathrm{T}}$ but missing from the nonsystemic crucifer leaf spot pathogen, $X$. campestris pv. armoraciae 417. Among the DNA fragments unique to $528^{\mathrm{T}}$ was Xcc2109, one of eight putative avr genes identified in the published $5^{2} 8^{\mathrm{T}}$ genome (NC_003902). Individual and sequential deletion, insertion mutations, or both of all eight $528^{\mathrm{T}}$ avr gene loci were made, but no change in pathogenicity was observed with any combination of avr mutations, including a strain with all eight $a v r$ genes deleted. However, insertion or deletion mutants affecting the Xcc2109 locus lost avirulence (i.e., became virulent) on Florida Mustard, an X. campestris pv. campestris race-determining, differential host. The Xcc2109 open reading frame as annotated was cloned and found to be nonfunctional. A longer gene, encompassing Xcc2109 and here designated $\operatorname{avrXccFM}$, was cloned and found to complement the Xcc2109 mutants and to confer avirulence to two additional wild-type $X$. campestris $\mathrm{pv}$. campestris strains, thereby changing their races. Resistance in Florida Mustard to $\mathbf{5 2 8}^{\mathrm{T}}$ strains carrying avrXccFM occurred without a typical hypersensitive response (HR) on leaves, although a vascular HR was observed in seedlings.
\end{abstract}

Additional keywords: chaperones, effectors, gene-for-gene, hrp, horizontal transfer, PCR, splice-overlap, type III secretion.

Xanthomonas campestris pv. campestris is a xylem-colonizing systemic pathogen that causes black rot of crucifers, a devastating disease worldwide. Xanthomonas campestris pv. armoraciae (McCulloch 1929) Dye 1978b also infects crucifers but not systemically and causes only localized leaf spots in the mesophyl and also hydathode necrosis (Black and Machmud 1983). Genes contributing to systemic movement of $X$. campestris pv. campestris or limiting systemic movement of $X$. campestris pv. armoraciae have not yet been identified. As with other xanthomonads, hypersensitive response and pathogenicity ( $h r p$ ) gene mutations in X. campestris pv. campestris result in a loss of both the ability to induce a hypersensitive response (HR) on nonhosts and pathogenicity on hosts (Daniels et al. 1988; Kamoun and Kado 1990), indicating that type III secretion (Alfano and Collmer 2004; Jin and He 2001) is criti-

Corresponding author: D. W. Gabriel; Telephone: +1.352.392.7877; Fax: +1.352.392.6532, E-mail: gabriel@ biotech.ufl.edu cal for pathogenicity of $X$. campestris pv. campestris. However, no type III effectors needed for pathogenicity of $X$. campestris pv. campestris have yet been identified. Three type III effecttors of the AvrBs3 family have been shown to contribute additively to the pathogenicity of $X$. campestris pv. armoraciae (Kay et al. 2005).

Specialized methods have been developed to identify type III effectors (Buttner et al. 2003; Nomura and He 2005), including reporter gene fusions (Cunnac et al. 2004; Guttman et al. 2002; Roden et al. 2004a), genomic analyses for plant inducible-promoter (PIP) consensus signatures (Mukaihara et al. 2004) and promoter-trap assays (Losada et al. 2004). More general methods have also been effectively used to identify bacterial genes contributing to pathogenicity, whether type III effectors or not, including chemical and transposon mutagenesis (Daniels et al. 1988; Kingsley et al. 1993), pathogenicity enhancement assays (Chen et al. 1994; Swarup et al. 1991), and suppression subtractive hybridization (SSH) (Golubov et al. 2003; Harakava and Gabriel 2003).

The purpose of this study was to identify $X$. campestris pv. campestris genes that contribute to either systemic movement or pathogenicity or both, whether by type III secretion or otherwise. When SSH was applied using X. campestris pv. campestris $528^{\mathrm{T}}$ as tester and $X$. campestris pv. armoraciae 417 as driver, a putative avirulence ( $a v r$ ) gene was found in $528^{\mathrm{T}}$ but not 417 . A search of the annotated genome of $528^{\mathrm{T}}$ (NC_003902; Xanthomonas-ONSA FAPESP network) revealed a total of seven additional putative avr genes (Xcc052, Xcc1629, Xcc2099, Xcc2100, Xcc2109, Xcc2396, Xcc3731, and Xcc4229). Since several studies have shown that bacterial avr genes encode type III effectors that often function for pathogenicity (Badel et al. 2003; Lin and Martin 2005; Lorang et al. 1994; Wichmann and Bergelson 2004; Yang et al. 1996), this study was focused on the potential role of all annotated $528^{\mathrm{T}}$ $a v r$ genes in pathogenicity. Individual and collective mutagenesis of all eight putative $a v r$ genes in $528^{\mathrm{T}}$ was performed by using splice overlap polymerase chain reaction (PCR) and marker-interruption techniques.

\section{RESULTS}

Suppression subtractive hybridization revealed an $X$. campestris pv. campestris avr gene.

In an initial screen to find genes present in (systemic) $X$. campestris pv. campestris but absent in (nonsystemic) $X$. campestris pv. armoraciae, SSH was performed using $X$. campestris pv. campestris $528^{\mathrm{T}}$ as tester against $X$. campestris pv. armora- 
ciae 417 as driver. Dot-blot analyses showed that about half of the $528^{\mathrm{T}}$ clones identified in the SSH screen were not present in 417 (data not shown). A total of 226 clones found in $528^{\mathrm{T}}$ but not in 417 after dot-blot analyses were sequenced. From these $528^{\mathrm{T}}$ fragments, 119 corresponded to hypothetical proteins, 11 to enzymatic proteins, 2 to two-component system proteins, and 1 to a predicted Avr protein (Xcc2109), among others. No other potential plant effectors were identified. A total of 21 transposable elements and related genes were also found in $528^{\mathrm{T}}$ and not in 417 . Genes of particular interest were also confirmed as present in $528^{\mathrm{T}}$ and missing in 417 by Southern hybridization (data not shown).

\section{No evidence of pathogenicity function} by any individual $528^{\mathrm{T}}$ avr gene or $X o p D$.

To test if any putative $a v r$ gene in $528^{\mathrm{T}}$ functioned for pathogenicity, all eight $a v r$ genes and a xopD homolog, Xcc2896, were individually mutated using marker interruption (Fig. 1A, Table 1). Mutagenesis was confirmed by PCR and Southern hybridization (data not shown), and mutants were inoculated on cabbage, white turnip, Seven Top turnip, and radish at two concentrations. No differences in pathogenicity were observed among the mutant and wild-type strains at either of the concentrations tested.

\section{No evidence of collective pathogenicity function} by all annotated $528^{\mathrm{T}}$ avr genes.

Collective mutagenesis of all eight annotated $a v r$ genes in $528^{\mathrm{T}}$ was performed primarily by using splice overlap PCRmediated gene deletion (Fig. 1C). This technique proved to be very efficient in $528^{\mathrm{T}}$; new mutations were usually made and verified within two weeks. Two different series of sequential, additive mutations in the $528^{\mathrm{T}}$ avr genes were constructed, using the X21 and X37.2 mutants as starting strains to perform successive rounds of mutations (Table 1). The mutations were confirmed by PCR and Southern hybridization (Fig. 2). All mutants were screened initially on cabbage plants and later on white turnip, Seven Top turnip, and radish. No mutant strains, including X8.8, which has mutational deletions or insertions in all eight putative $528^{\mathrm{T}}$ avr genes, showed any alteration in pathogenicity when compared with the wild type. Growth kinetic studies in planta using wild-type $528^{\mathrm{T}}$ and strain X8.8 revealed that population dynamics in white turnip of the two

Fig. 1. Mutagenesis strategies used. A, Marker interruption. A DNA fragment internal (hatched) to the target open reading frame (ORF) (vertical bars denote start and stop codons) was cloned in a suicide vector and was introduced into the target strain. Following homologous recombination at the target site, a duplication of the cloned region occurred, and the vector became integrated between incomplete copies of the target gene. B, flp recognition target (FRT) interruption. A DNA fragment internal to the target ORF was cloned in a suicide vector between FRT sites. Following introduction into the target strain and homologous recombination as for marker interruption, the vector was deleted by addition of a second plasmid, encoding flippase (FLP) recombinase, into the target strain. FLP recombinase catalyzes recombination between two FRT sites, and this resulted in a single FRT "scar" in place of the vector. C, Splice-overlap polymerase chain reaction (PCR) (Horton et al. 1989). A region upstream and a region downstream of the target ORF were PCR-amplified and then fused to form a PCR product that carried both ends of the target ORF but not the target region. The PCR product was cloned into a suicide vector containing the $s a c B$ gene and was introduced into the target strain. Following homologous recombination at one of the target sites, a second homologous recombination event was selected on medium containing sucrose. Since only strains that have lost $s a c B$ survive on sucrose, double recombination was selected and, as a result, a deletion in the target gene was obtained. Arrows represent primers. Filled arrows represent FRT sites. Regions of homology are shown in boxes with vertical lines. strains was not significantly different up to 8 days postinoculation (Fig. 3).

\section{avrXccFM determines avirulence in $528^{\mathrm{T}}$}

on Florida Mustard without a typical HR.

$528^{\mathrm{T}}$ is a race $1 \mathrm{X}$. campestris pv. campestris strain that is avirulent on Florida Indian Mustard (Florida Mustard), one of four differential host cultivars (in three different species) used to determine races of $X$. campestris pv. campestris (Kamoun et
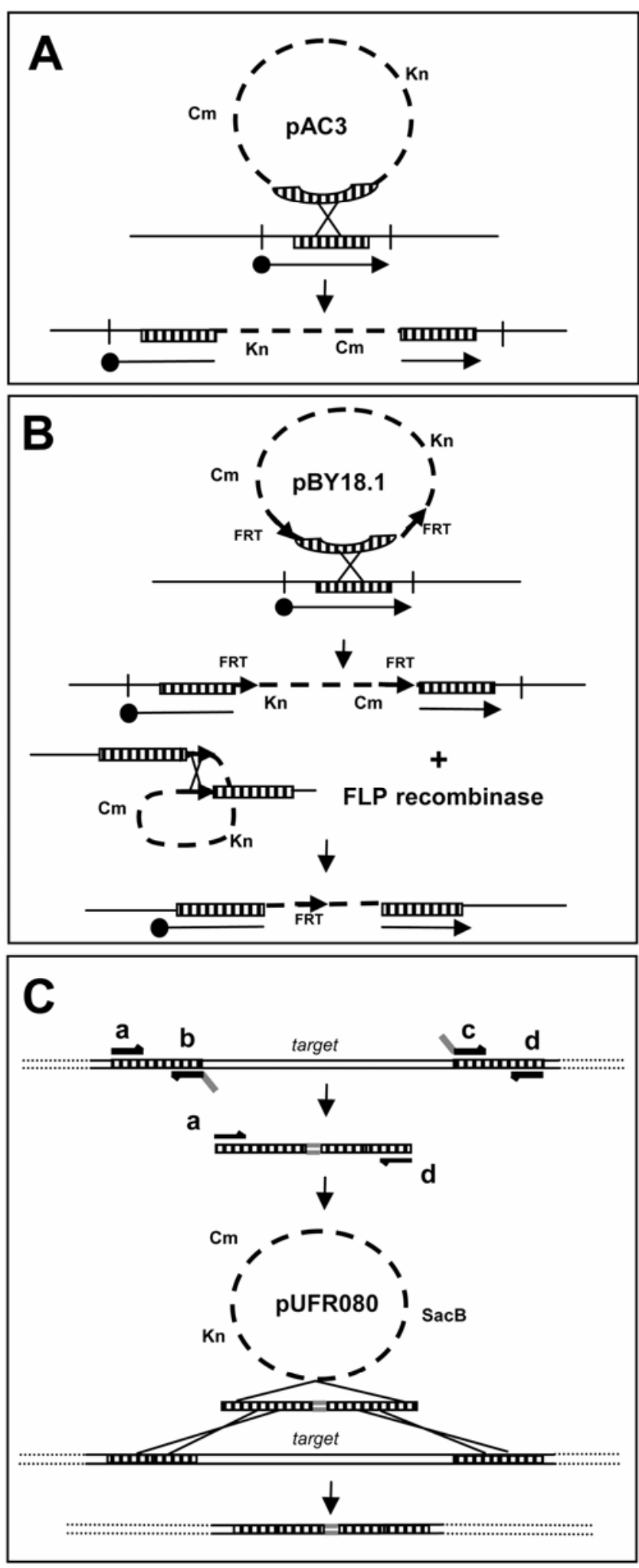
Table 1. Bacterial strains and plasmids

\begin{tabular}{|c|c|c|}
\hline Strains & Relevant characteristics ${ }^{\mathbf{a}}$ & Reference or source \\
\hline \multicolumn{3}{|l|}{ E. coli } \\
\hline E. coli $\mathrm{DH} 5 \alpha$ & $\begin{array}{l}\mathrm{F}^{-}, \text {endA1, hsdR17(rk-mk-), supE44, thi-1, recAl gyrA, relA1, f80d lacZDM15, }(\text { (lacZYA-argF) } \\
\text { U169 }\end{array}$ & $\begin{array}{l}\text { Invitrogen Corp. Carlsbad, CA, } \\
\text { U.S.A. }\end{array}$ \\
\hline E. coli $\mathrm{DH} 5 \alpha-\mathrm{T} 1$ & 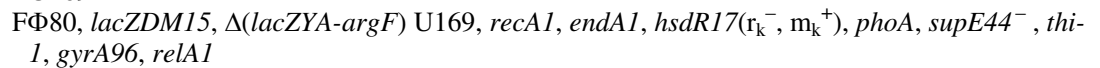 & Invitrogen Corp. \\
\hline \multicolumn{3}{|c|}{ so or } \\
\hline $95-2$ & Xanthomonas axonopodis pv. vesicatoria, wild-type, avrBs3+ & J. Jones, University of Florida \\
\hline 417 & Xanthomonas campestris pv. armoraciae wild-type & Alvarez et al. 1994 \\
\hline $3849 \mathrm{~A}$ & Xanthomonas campestris pv. campestris wild-type Race 2 & Kamoun and Kado 1992 \\
\hline 6181 & Xanthomonas campestris pv. campestris wild-type Race 0 & Vicente et al. 2001 \\
\hline $528^{\mathrm{T}}$ & $\begin{array}{l}\text { Xanthomonas campestris pv. campestris wild-type, Race 1, type strain of species, synonym: } \\
\text { ATCL33913 }\end{array}$ & Alvarez et al. 1994 \\
\hline $\mathrm{X} 54$ & $3849 \mathrm{~A} / \mathrm{pAC19}$ (avrXccFM in pUFR070), $\mathrm{Gm}^{\mathrm{r}}$ & This work \\
\hline X55 & $3849 \mathrm{~A} / \mathrm{pAC} 10(\mathrm{Xcc} 2109 \mathrm{in} \mathrm{pUFR} 070), \mathrm{Gm}^{\mathrm{r}}$ & This work \\
\hline $\mathrm{X} 83$ & $6181 / \mathrm{pAC} 19\left(\right.$ avrXccFM in pUFR070), $\mathrm{Gm}^{\mathrm{r}}$ & This work \\
\hline $\mathrm{X} 84$ & $6181 / \mathrm{pAC} 10$ (Xcc2109 in pUFR070), $\mathrm{Gm}^{\mathrm{r}}$ & This work \\
\hline \multicolumn{3}{|c|}{ 列 } \\
\hline $\mathrm{X} 05$ & Xcc0052::pAC7, Rif $^{\mathrm{r}}, \mathrm{Kn}^{\mathrm{r}}$ & This work \\
\hline $\mathrm{X} 16$ & Xcc1629::pUFR12 Rif $^{r}, \mathrm{Kn}^{\mathrm{r}}$ & This work \\
\hline X99 & Xcc2099::pAC7 iff $^{\mathrm{r}}, \mathrm{Kn}^{\mathrm{r}}$ & This work \\
\hline $\mathrm{X} 100$ & Xcc2100::pAC7 $\mathrm{Rif}^{\mathrm{r}}, \mathrm{Kn}^{\mathrm{r}}$ & This work \\
\hline X109 & Xcc2109::pAC7 Rif ${ }^{r}, \mathrm{Kn}^{\mathrm{r}}$ & This work \\
\hline $\mathrm{X} 23$ & Xcc2396::pAC7 $\mathrm{Rif}^{\mathrm{r}}, \mathrm{Kn}^{\mathrm{r}}$ & This work \\
\hline X37.1 & Xcc3731::pAC7 Rif $^{r}, \mathrm{Kn}^{\mathrm{r}}$ & This work \\
\hline $\mathrm{X} 42$ & Xcc4229::pAC7 $\mathrm{Rif}^{\mathrm{r}}, \mathrm{Kn}^{\mathrm{r}}$ & This work \\
\hline X48 & $\Delta \mathrm{Xcc} 2109 \mathrm{Rif}^{\mathrm{r}}$ & This work \\
\hline $\mathrm{X} 37.2$ & Xcc3731::FRT Rif ${ }^{\mathrm{r}}, \mathrm{Kn}^{\mathrm{r}}$ & This work \\
\hline $\mathrm{X} 44$ & Xcc2896::TOPO Rif ${ }^{r}, \mathrm{Kn}^{\mathrm{r}}$ & This work \\
\hline X49 & $\Delta$ Xcc2099, Xcc3731::pAC3.1, Rif $^{\mathrm{r}}, \mathrm{Kn}^{\mathrm{r}}$ & This work \\
\hline $\mathrm{X} 21$ & $\Delta \mathrm{Xcc} 2099, \Delta \mathrm{Xcc} 2100, \operatorname{Rif}^{\mathrm{r}}$ & This work \\
\hline $\mathrm{X} 4.4$ & $\Delta$ Xcc0052, Xcc3731::FRT, Rif $^{r}$ & This work \\
\hline $\mathrm{X} 4.1$ & Xcc3731::FRT, $\Delta$ Xcc2099, $\Delta$ Xec2100, Rif $^{\mathrm{r}}$ & This work \\
\hline $\mathrm{X} 5.1$ & $\Delta \mathrm{Xcc} 2099, \Delta \mathrm{Xcc} 2100, \Delta \mathrm{Xcc} 2109, \mathrm{Rif}^{\mathrm{r}}$ & This work \\
\hline X6.1 & $\Delta \mathrm{Xcc} 0052, \Delta \mathrm{Xcc} 2099, \Delta \mathrm{Xcc} 2100, \mathrm{Rif}^{\mathrm{r}}$ & This work \\
\hline $\mathrm{X} 12.1$ & Xcc3731::FRT, $\Delta$ Xcc2099, Xcc2100, $\Delta$ Xcc2109, Rif $^{\mathrm{r}}$ & This work \\
\hline $\mathrm{X} 2.1$ & $\Delta \mathrm{Xcc} 0052, \Delta \mathrm{Xcc} 2099, \Delta \mathrm{Xcc}^{2} 100, \Delta \mathrm{Xcc}^{2} 109, \mathrm{Rif}^{\mathrm{r}}$ & This work \\
\hline $\mathrm{X} 1.1$ & $\Delta \mathrm{Xcc} 0052, \Delta \mathrm{Xcc} 2099, \Delta \mathrm{Xcc} 2100, \Delta \mathrm{Xcc} 2109, \mathrm{Xcc} 3731:: \mathrm{FRT}, \mathrm{Rif}^{\mathrm{r}}$ & This work \\
\hline $\mathrm{X} 5.5$ & $\Delta \mathrm{Xcc} 0052, \Delta \mathrm{Xcc} 2099, \Delta \mathrm{Xcc} 2100, \Delta \mathrm{Xcc} 2109, \Delta \mathrm{Xcc} 2396, \operatorname{Rif}^{\mathrm{r}}$ & This work \\
\hline X6.6 & $\Delta \mathrm{Xcc} 0052, \Delta \mathrm{Xcc} 2099, \Delta \mathrm{Xcc} 2100, \Delta \mathrm{Xcc} 2109, \Delta \mathrm{Xcc} 2396, \mathrm{Xcc}^{2} 731:: \mathrm{FRT}, \mathrm{Rif}^{\mathrm{r}}$ & This work \\
\hline X6.7 & $\Delta \mathrm{Xcc} 0052, \Delta \mathrm{Xcc} 2099, \Delta \mathrm{Xcc} 2100, \Delta \mathrm{Xcc} 2109, \Delta \mathrm{Xcc} 2396, \Delta \mathrm{Xcc} 4229, \mathrm{Rif}^{\mathrm{r}}$ & This work \\
\hline X7.7 & $\Delta$ Xec0052, $\Delta$ Xcc2099, $\Delta$ Xec2100, $\Delta$ Xcc2109, $\Delta$ Xcc2396, Xcc3731::FRT, $\Delta$ Xcc4229, Rif $^{r}$ & This work \\
\hline $\mathrm{X} 7.8$ & $\Delta \mathrm{Xcc} 0052, \Delta \mathrm{Xcc} 2099, \Delta \mathrm{Xcc} 2100, \Delta \mathrm{Xcc} 2109, \Delta \mathrm{Xcc} 2396, \Delta \mathrm{Xcc} 3731, \Delta \mathrm{Xcc}^{2} 229, \operatorname{Rif}^{\mathrm{r}}$ & This work \\
\hline $\mathrm{X} 8.8$ & 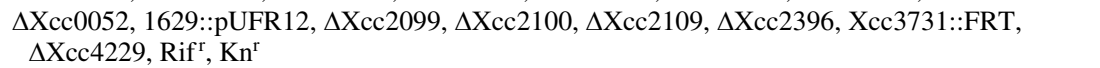 & This work \\
\hline $\mathrm{X} 8.10$ & $\begin{array}{l}\Delta \mathrm{Xcc} 0052, \Delta \mathrm{Xcc}^{2099}, \Delta \mathrm{Xcc} 2100, \Delta \mathrm{Xcc} 2109, \Delta \mathrm{Xcc} 2396, \mathrm{Xcc} 2896:: T O P O, \Delta \mathrm{Xcc} 3731, \\
\Delta \mathrm{Xcc} 4229, \mathrm{Rif}^{\mathrm{r}}, \mathrm{Kn}^{\mathrm{r}}\end{array}$ & This work \\
\hline $\mathrm{X} 50$ & X48/pAC10 (Xcc2109), Rif $^{r}, \mathrm{Gm}^{\mathrm{r}}$ & This work \\
\hline X52 & $\mathrm{X} 48 / \mathrm{pAC} 19(a v r X c c F M), \mathrm{Rif}^{\mathrm{r}}, \mathrm{Gm}^{\mathrm{r}}$ & This work \\
\hline $\mathrm{X} 111$ & X109/pAC10 (Xcc2109), $\operatorname{Rif}^{\mathrm{r}}, \mathrm{Kn}^{\mathrm{r}}, \mathrm{Gm}^{\mathrm{r}}$ & This work \\
\hline $\mathrm{X} 113$ & $\mathrm{X} 109 / \mathrm{pAC} 19($ avrXccFM $), \mathrm{Rif}^{\mathrm{r}}, \mathrm{Kn}^{\mathrm{r}}, \mathrm{Gm}^{\mathrm{r}}$ & This work \\
\hline \multicolumn{3}{|c|}{ (2) } \\
\hline TOPO & PCR cloning vector, $\mathrm{Ap}^{\mathrm{r}}, \mathrm{Kn}^{\mathrm{r}}$ & Invitrogen Corp. \\
\hline pGEMTez & PCR cloning vector, $\mathrm{Ap}^{\mathrm{r}}$ & Promega, Madison, WI, U.S.A. \\
\hline pUFR004 & $\mathrm{ColE} 1, \mathrm{Mob}+, \mathrm{lacZ} \alpha+, \mathrm{Cm}^{\mathrm{r}}$ & De Feyter et al. 1990 \\
\hline pUFR012 & ColE1, Mob+, lacZ $\alpha+, \mathrm{Cm}^{\mathrm{r}}, \mathrm{Kn}^{\mathrm{r}}$ & This work \\
\hline pUFR047 & $\mathrm{IncW}, \mathrm{Mob}+, \mathrm{lacZ} \alpha+, \mathrm{Par}+, \mathrm{Gm}^{\mathrm{r}}, \mathrm{Ap}^{\mathrm{r}}$ & De Feyter et al. 1993 \\
\hline pUFR070 & $\mathrm{IncW}, \mathrm{Mob}+, \mathrm{lacZ} \alpha+, \mathrm{Par}+, \mathrm{Gm}^{\mathrm{r}}, \mathrm{Cm}^{\mathrm{r}}$ & This work \\
\hline pUFR080 & $S a c B$ gene cloned into DraIII site of pAC3.1. ColE1, Mob+, lacZ $\alpha+, S a c B, \mathrm{Cm}^{\mathrm{r}}, \mathrm{Kn}^{\mathrm{r}}$ & This work \\
\hline pAC3.1 & Derivative of pUFR004. ColE1, Mob+, lacZ $\alpha+, \mathrm{Cm}^{\mathrm{r}}, \mathrm{Kn}^{\mathrm{r}}$ & This work \\
\hline pAC7 & Derivative of pUFR004. ColE1, Mob+, $\mathrm{Cm}^{\mathrm{r}}, \mathrm{Kn}^{\mathrm{r}}$ & This work \\
\hline pUC118 & ColE1, M13, lacZ $\alpha+, \mathrm{Ap}^{\mathrm{r}}$ & Yanisch-Perron et al. 1985 \\
\hline pFLP2 & ColE1, $\mathrm{sacB}^{+}, f l p^{+}$(Cro promoter), $\mathrm{Ap}^{\mathrm{r}}$ & Hoang et al. 1998 \\
\hline pJR4 & $\begin{array}{l}s a c B^{+} \text {and } f_{l}^{+} \text {(Cro promoter) from pFLP2 cloned into pUFR47. IncW, Mob+, lacZ } \alpha+\text {, Part, } \\
s a c B^{+}, \text {flp }^{+} \text {(Cro promoter), } \mathrm{Gm}^{\mathrm{r}}, \mathrm{Ap}^{\mathrm{r}}\end{array}$ & This work \\
\hline pKD4 & FRT-Kn ${ }^{\mathrm{r}}-\mathrm{FRT}$, oriR6K, $\mathrm{Ap}^{\mathrm{r}}, \mathrm{Kn}^{\mathrm{r}}$ & Datsenko and Wanner 2000 \\
\hline pKLN66 & $\mathrm{Kn}^{\mathrm{r}}$ gene in pGEMT-ez derivative of pKLN56 & Newman et al. 2003 \\
\hline pBY17.1 & FRT sites from $\mathrm{pKD} 4$ recloned into $\mathrm{pAC} 3.1 . \mathrm{Cm}^{\mathrm{r}}, \mathrm{Kn}^{\mathrm{r}}$ & This work \\
\hline $\mathrm{pAC} 10$ & Xcc2109 ORF (2492436..2493431 of NC_003902) cloned into pUFR70. $\mathrm{Gm}^{\mathrm{r}}, \mathrm{Cm}^{\mathrm{r}}$ & This work \\
\hline pAC19 & $\operatorname{avrXccFM}\left(2492436-2493431\right.$ of NC_003902) cloned into pUFR070. $\mathrm{Gm}^{\mathrm{r}}, \mathrm{Cm}^{\mathrm{r}}$ & This work \\
\hline
\end{tabular}

${ }^{\mathrm{a}} \mathrm{Ap}=$ ampicillin, $\mathrm{Gm}=$ getamicin, $\mathrm{Cm}=$ chloramphenicol, $\mathrm{Kn}=$ kanamycin, $\mathrm{Rif}=$ rifampicin, $\mathrm{ORF}=$ open reading frame.

${ }^{\mathrm{b}}$ All marker-interruption mutations are indicated by novel joint fusions of the indicated plasmid and the indicated 528 ${ }^{\mathrm{T}}$ locus. All flippase (FLP) recombinase mutations are indicated by novel joint fusions of the indicated $528^{\mathrm{T}}$ locus with the flp recognition target (FRT) scar. All deletion derivatives were made by splice-overlap polymerase chain reaction (PCR) at the indicated $528^{\mathrm{T}}$ locus. 
al. 1992). Strain $528^{\mathrm{T}}$ elicited neither disease symptoms nor an HR on leaves of Florida Mustard, although it did elicit a vascular HR in seedlings of Florida Mustard (not shown). No significant electrolyte leakage was observed in leaves of Florida Mustard inoculated with $528^{\mathrm{T}}$ even $120 \mathrm{~h}$ after inoculation (Fig. 4). By contrast, X. campestris pv. armoraciae 417, which elicited an HR on leaves, exhibited greatly increased electrolyte leakage beginning $24 \mathrm{~h}$ after inoculation.

By contrast with the wild type, all mutant strains carrying single or multiple mutations and affecting the Xcc2109 locus of $528^{\mathrm{T}}$, whether obtained by marker interruption (e.g., X48) or by splice overlap PCR (e.g., X109), caused systemic pathogenic symptoms on leaves of Florida Mustard, including progressive chlorosis and necrosis outside of the immediate inoculation zone or zones (Fig. 5; Table 2). These symptoms occurred as early as 4 days after inoculation, whether inoculated at high or low concentration. All Xcc2109 mutants also failed to induce the vascular HR on seedlings elicited by the wild-type $528^{\mathrm{T}}$ strain (not shown). These mutations created a race change from the wild-type $528^{\mathrm{T}}$ race 1 to race 0 (Table 3 ), indicating that Xcc2109 was in fact an $a v r$ gene locus.

da Silva and associates (2002), annotated the Xcc2109 open reading frame (ORF) as avrXccC, 996 nucleotides long and encoding 332 amino acids. pAC10, carrying this ORF translationally fused to a 5-amino acid LacZ leader, failed to complement X48 and X109. Further analysis of the Xcc2109 locus indicated that the functional gene was more likely $1,323 \mathrm{bp}$ long, encoding 441 amino acids and starting 327 bp upstream from the annotated start site. This longer gene, here designated avrXccFM (avirulence of $X$. campestris pv. campestris on Florida Mustard), contains a Shine-Dalgarno (SD) region -11 bp from the start site (2493758 in NC_003902) and a putative PIP box in the promoter region -67 and -83 bp from the start site (TTCG...N16...TTCG). The 1,323-bp $a v r X c c F$ with its native SD and driven by the lacZ promoter in pAC19 comple- mented X48 and X109. Transformants of X48 and X109 carrying pAC19 (avrXccFM) were as avirulent on Florida Mustard leaves as the wild-type strain $528^{\mathrm{T}}$ (Fig. 5). These transformants also restored the vascular HR on seedlings identical to $528^{\mathrm{T}}$ (data not shown) and completely suppressed the electrolyte leakage otherwise elicited by X48 in inoculated leaves to levels identical to $528^{\mathrm{T}}$ (Fig. 4).

\section{avrXccFM confers race-specific avirulence}

to $X$. campestris pv. campestris strains of other races.

Strain 6181 belongs to $X$. campestris pv. campestris race 0 and $3849 \mathrm{~A}$ belongs to $X$. campestris pv. campestris race 2, based on the host differentials proposed by Kamoun and associates (1992). Southern blot analyses revealed that avrXccFM did not hybridize with DNA extracted from either of these strains (not shown). When pAC19 ( $\operatorname{vr} X c c F M)$ was introduced into strain 6181, the transformant elicited much

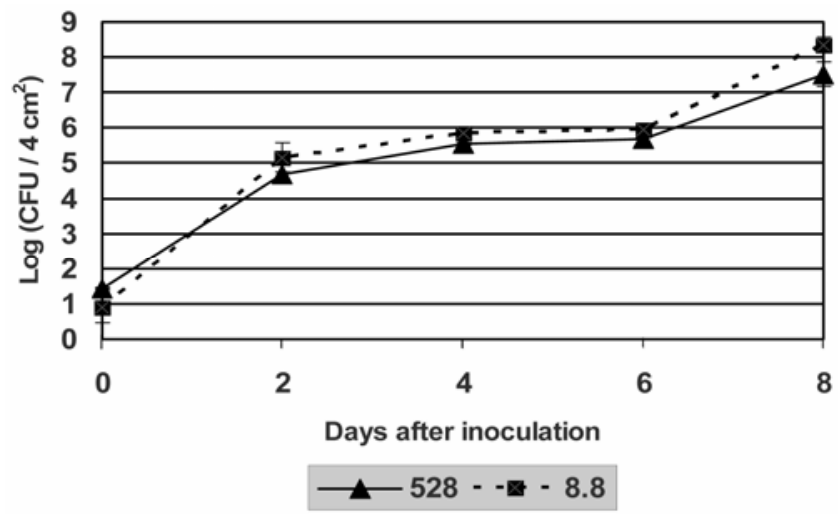

Fig. 3. Growth of wild-type $528^{\mathrm{T}}$ and $\mathrm{X} 8.8$ (all eight $a v r$ genes interrupted or deleted) in white turnip cultivar Hakurei Hybrid.
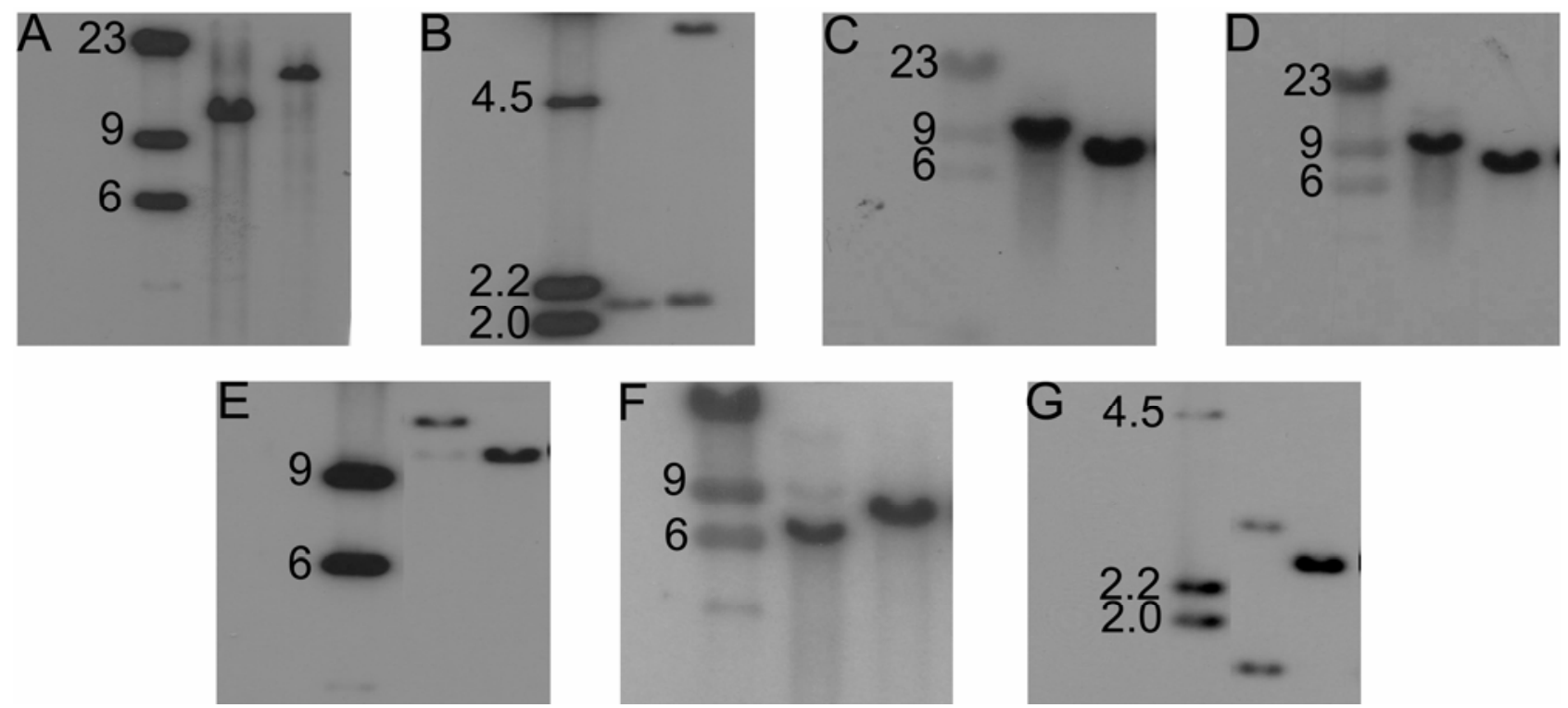

Fig. 2. Southern blots of $528^{\mathrm{T}}$ wild type and X8.8 (mutated in eight annotated avr genes) DNA, digested with EcoRI. On each blot, from left to right: $\lambda$ HindIII marker, wild type 528 ${ }^{\mathrm{T}}$, and mutant strain X8.8. Except for Xcc1629 (marker-interrupted) and Xcc3731 (flp recognition target [FRT] interrupted), all other avr gene loci (as annotated) were entirely deleted by splice-overlap polymerase chain reaction (PCR). Probes used were DNA fragments amplified with the following PCR primer sets or DNA fragments amplified and cloned in TOPO or pUFR080. A, 52C-52D1 to detect Xcc0052 deletion-loss of an EcoRI site results in a larger hybridizing fragment of expected size; B, AC5-AC-6 to detect Xcc1629 interruption-integration of the suicide vector introduces a new EcoRI site and results in two larger fragments of expected size; C, 2099A-2099D to detect simultaneous deletion of both Xcc2099 and Xcc2100, resulting in a smaller fragment of expected size; D, AC35-AC45 to detect deletion of Xcc2109, resulting in a smaller fragment of expected size, E, 2396A12396D to detect deletion of Xcc2396, resulting in a smaller fragment of expected size; F, AC32-AC48 to detect interruption of Xcc3731 by an FRT site, resulting in a larger fragment containing an internal region duplication and the FRT scar of expected size, and G, 4229A-4229D to detect deletion of Xcc4229, resulting in loss of an EcoRI site and creation of a single fragment of expected size. 
smaller lesions in Florida Mustard compared with those in the 6181 wild type (Fig. 6), and the bacterial titer in planta was 10 to 100 times lower than found in the wild type (Fig. 7). Introduction of pAC19, therefore, caused a change of 6181 from race 0 to a new and previously uncharacterized race (Table 3). Similarly, when pAC19 was introduced into strain 3849A, the transformant elicited no lesions at all and became avirulent on Florida Mustard plants, resulting in a change of 3849A from race 2 to yet another new and previously uncharacterized race (Fig. 6; Table 3). These results confirmed that $a v r X c c F M$ is an active, race-determining $a v r$ gene recognized by Florida Mustard plants. When pAC10 carrying the truncated $a v r X c c F M$ (Xcc2109) was introduced into either strain 6181 or 3849 A, no effect on virulence was observed on the set of host differentials. (The term "virulence" is used in this paper in a gene-for-gene sense as the antonym of avirulence [Gabriel 2001]).

\section{No evidence of effect of $528^{\mathrm{T}}$ avr mutants on two nonhosts.}

All X. campestris pv. campestris avr mutants and mutant combinations were inoculated on nonhost pepper plants ECW, ECW-10R, ECW-20R, and ECW-30R at four different concentrations. No change in intensity of the HR from that elicited by the wild type was observed after $48 \mathrm{~h}$ in any of the plants tested (Table 2). Similarly, all X. campestris pv. campestris avr mutants and mutant combinations were inoculated on Arabidopsis thaliana ecotypes Coi-1 and Col-0 and no change from

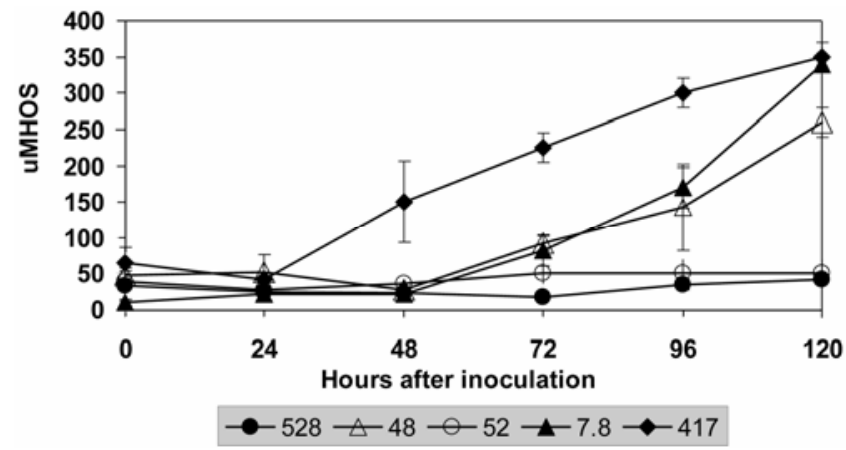

Fig. 4. Timecourse of electrolyte leakage from leaves of Florida Mustard plants inoculated with Xanthomonas campestris pv. campestris wild-type strain $528^{\mathrm{T}}$, three of its mutants and $X$. campestris pv. armoraciae 417. the null response elicited by the wild type was observed after $48 \mathrm{~h}$ (Table 2).

\section{DISCUSSION}

Genomic analysis of $X$. campestris pv. campestris $528^{\mathrm{T}}$ showed that numerous horizontal gene-transfer events probably occurred in this strain; 109 genes related to transposable elements, as well as extended regions with low percent $\mathrm{G}+\mathrm{C}$ content and uncommon codon usage were found (da Silva et al. 2002). Further analysis revealed at least 285 genes in $528^{\mathrm{T}}$ that appear to have been horizontally acquired (Garcia-Vallvé et al. 2003), including three of the eight putative avr gene homologs investigated in this study.

It is often assumed that, when avr genes are acquired through horizontal gene transfer, they become fixed in the bacterial genome because they confer a selective advantage in terms of pathogenicity (Alfano and Collmer 2004; Rohmer et al. 2004). Pleiotropic pathogenicity effects are a common-but not universal-feature of $a v r$ genes and have been reported in several pathogen species (Abramovitch et al. 2003; Alfano and Collmer 2004; Badel et al. 2003; Bogdanove et al. 1998; Kearney and Staskawicz 1990; Lorang et al. 1994; Swarup et al. 1992; Wichmann and Bergelson 2004; Yang et al. 1996). Once fixed in the genome, the percent $\mathrm{G}+\mathrm{C}$ content of an acquired gene with selective value may gradually evolve to match that of the recipient (Hacker and Kaper 2000; Lawrence and Ochman 1997). Since five of the eight putative $528^{\mathrm{T}} a v r$ genes studied were not identified as being horizontally transferred by Garcia-Vallvé and associates $(2003)$, adaptation to $528^{\mathrm{T}}$ and a selective value in terms of pathogenicity for these five might seem particularly likely.

Nevertheless, none of the eight putative $a v r$ gene loci, when deleted or interrupted in $528^{\mathrm{T}}$, affected pathogenicity on any of the six cruciferous host differential species tested in growth chambers. Furthermore, they did not appear to confer any pathogenic effect even in an additive way, since inoculations of strain X8.8 (all eight putative $a v r$ gene loci mutated) was as pathogenic as the wild type when inoculated onto five susceptible Brassica species. Growth kinetic studies confirmed no differences between wild type and X8.8 in infections of white turnip plants.

Some effector genes found in Pseudomonas spp., including $a v r$ genes, are known to suppress host defenses, as indicated by suppression of the HR (Abramovith et al. 2003; Alfano and
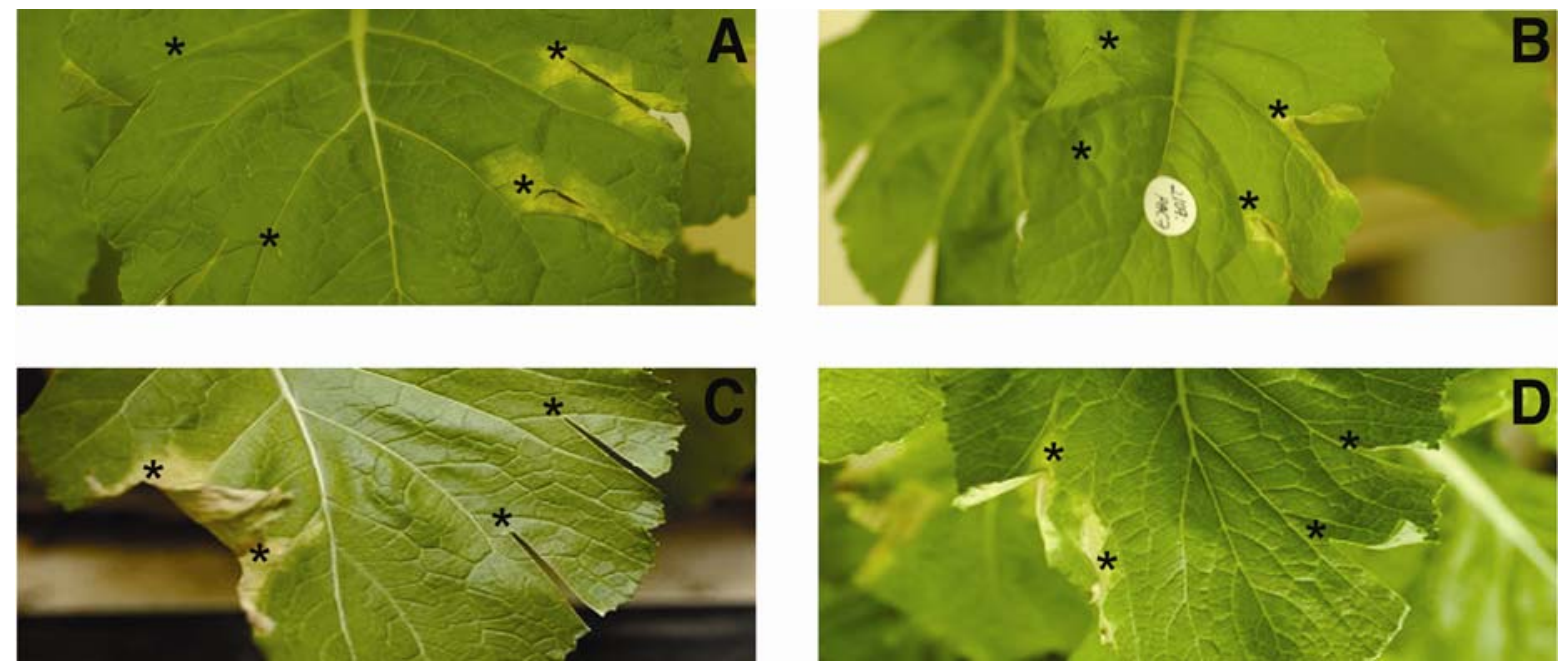

Fig. 5. Florida Mustard plants scissor-inoculated with wild-type $528^{\mathrm{T}}$ and selected mutant strains at $10^{5} \mathrm{CFU} / \mathrm{ml}$. Asterisks indicate the inoculation sites. A, $528^{\mathrm{T}}$, left; X48 ( $\left.\triangle \mathrm{Xcc} 2109\right)$, right. B, $528^{\mathrm{T}}$ left; X109 (Xcc2109::pAC7), right. C, X48, left; X52 (X48/(avrXccFM), right. D, X109, left; X113 $(\mathrm{X} 109 / \mathrm{avrXccFM})$, right. Photos taken 7 days after inoculation. 
Collmer 2004). Indeed, Kamoun and associates (1992) provided evidence for host-defense suppression by $X$. campestris pv. campestris; mutations affecting the entire $X$. campestris $\mathrm{pv}$. campestris hrp system result in the appearance of a vascular HR in inoculated seedling stems that is not elicited by wildtype $X$. campestris pv. campestris strains. The one or more effectors involved have not been identified. However, none of
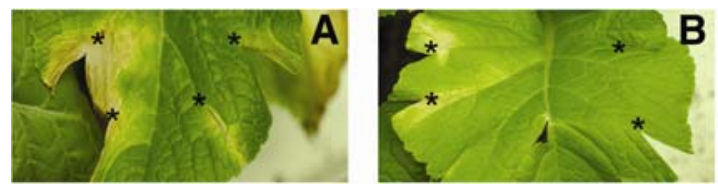

Fig. 6. Race changes observed with transformants of strains from two different Xanthomonas campestris pv. campestris races carrying avrXccFM scissor-inoculated at $10^{5} \mathrm{CFU} / \mathrm{ml}$. Asterisks indicate the inoculation sites. A, $X$. campestris pv. campestris race 0 strain 6181, left; 6181/avrXccFM, right. Photo taken 7 days after inoculation. B, X. campestris pv. campestris race 2 strain 3189A, left; 3189A/ avrXccFM, right. Photo taken 14 days after inoculation. the eight avr genes found in the $528^{\mathrm{T}}$ genome and tested by mutational analysis in this study appeared to encode effectors that suppress this vascular HR, individually or collectively. Furthermore, none of the avr genes found in $528^{\mathrm{T}}$, singly or in

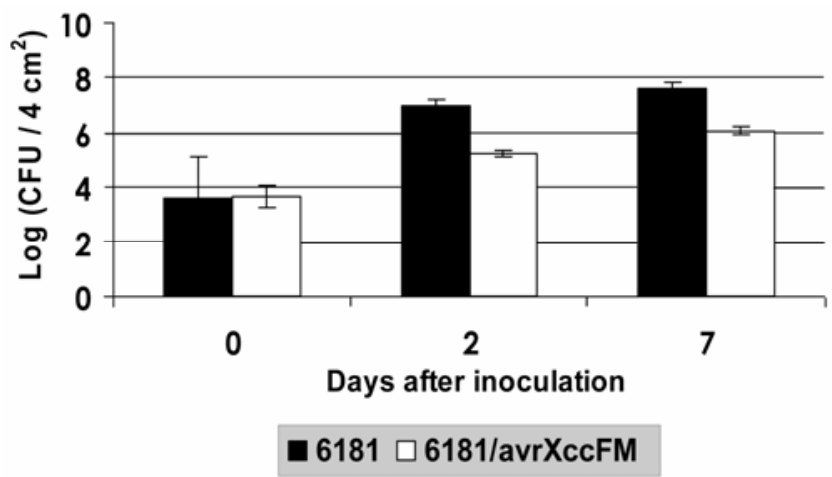

Fig. 7. Growth of Xanthomonas campestris pv. campestris 6181 and its transformant X83 (6181/avrXccFM) in Florida Mustard.

Table 2. Disease symptoms on five crucifer hosts and a nonhost species after inoculation with Xanthomonas campestris pv. campestris $528^{\mathrm{T}}$ and mutant strains

\begin{tabular}{|c|c|c|c|c|c|c|}
\hline X. campestris pv. campestris strains & Arabidopsis thaliana $^{\mathrm{a}}$ & Cabbage & Turnip & Radish & Mustard & Pepper \\
\hline $528^{\mathrm{T}}$ & $\varnothing$ & + & + & + & $\varnothing$ & HR \\
\hline X05 & $\mathrm{ND}^{\mathrm{b}}$ & + & + & + & $\widetilde{\varnothing}$ & HR \\
\hline X16 & ND & + & + & + & $\varnothing$ & HR \\
\hline X99 & ND & + & + & + & $\varnothing$ & HR \\
\hline X100 & ND & + & + & + & $\varnothing$ & HR \\
\hline $\mathrm{X} 109 * \mathrm{c}$ & ND & + & + & + & + & HR \\
\hline X23 & ND & + & + & + & $\varnothing$ & HR \\
\hline X3731 & ND & + & + & + & $\varnothing$ & HR \\
\hline X42 & ND & + & + & + & $\varnothing$ & HR \\
\hline $\mathrm{X} 48^{*}$ & $\varnothing$ & + & + & + & + & HR \\
\hline X37.2 & $\varnothing$ & + & + & + & $\varnothing$ & HR \\
\hline X44 & ND & + & + & + & ND & ND \\
\hline $\mathrm{X} 49 *$ & ND & ND & ND & ND & + & ND \\
\hline X21 & ND & + & + & + & $\varnothing$ & HR \\
\hline X $5.1^{*}$ & $\varnothing$ & + & + & + & + & ND \\
\hline X6.1 & $\varnothing$ & + & + & + & $\varnothing$ & HR \\
\hline $\mathrm{X} 2.1 *$ & $\varnothing$ & + & + & + & + & ND \\
\hline $\mathrm{X} 5.5^{*}$ & ND & + & + & + & + & HR \\
\hline $\mathrm{X} 6.7^{*}$ & ND & ND & ND & ND & + & ND \\
\hline X7.8* & ND & ND & ND & ND & + & ND \\
\hline X8.8* & ND & + & ND & + & ND & HR \\
\hline $\mathrm{X} 8.10 *$ & $\varnothing$ & ND & + & ND & + & ND \\
\hline $\mathrm{X} 50 *(\mathrm{X} 48 / \mathrm{pAC} 10)$ & ND & ND & + & ND & + & ND \\
\hline X52 (X48/pAC19) & ND & ND & + & ND & $\varnothing$ & ND \\
\hline $\mathrm{X} 111 *(\mathrm{X} 109 / \mathrm{pAC} 10)$ & ND & ND & + & ND & + & ND \\
\hline X113 (X109/pAC19) & ND & ND & + & ND & $\varnothing$ & ND \\
\hline $3849 A^{*}$ & ND & + & + & ND & + & ND \\
\hline $\mathrm{X} 53 *(3849 \mathrm{~A} / \mathrm{pAC} 10)$ & ND & ND & + & ND & + & ND \\
\hline X54 (3849A/pAC19) & ND & ND & + & ND & $\varnothing$ & ND \\
\hline $6181 *$ & ND & + & + & ND & + & ND \\
\hline $\mathrm{X} 82 *(6181 / \mathrm{pAC} 10)$ & ND & ND & + & ND & + & ND \\
\hline X83 (6181/pAC19) & ND & ND & + & ND & $(+)$ & ND \\
\hline
\end{tabular}

a Plant cultivars used were: Arabidopsis thaliana, ecotypes Coi-1 and Col-0; cabbage, Early Jersey Wakefield; turnip, Hakurei Hybrid; radish, Sparkler Radish; mustard, Florida Broad Leaf Indian Mustard; and pepper, ECW, ECW10R, ECW20R, ECW30R.

${ }^{\mathrm{b}} \mathrm{ND}=$ not determined; + = typical black rot symptoms; $(+)=$ reduced black rot symptoms; $\varnothing=$ null response; HR = hypersensitive response.

${ }^{c}$ An asterisk (*) indicates strains in which the Xcc2109 locus (avrXccFM) was deleted, interrupted, or absent.

Table 3. Race changes determined by $a v r X c c F M$ addition or deletion in three Xanthomonas campestris pv. campestris strains ${ }^{\mathrm{a}}$

\begin{tabular}{|c|c|c|c|c|}
\hline Xanthomonas strains & Early Jersey Wakefield & Just Right Turnip & Seven Top Turnip & Florida Broad Leaf Indian Mustard \\
\hline $528^{\mathrm{T}}($ avrXccFM $)$ race 1 & + & + & + & $\varnothing$ \\
\hline $\mathrm{X} 48\left(528^{\mathrm{T}} \Delta a v r X c c F M\right)$ race 0 & + & + & + & + \\
\hline $\mathrm{X} 52\left(528^{\mathrm{T}} \Delta\right.$ avrXccFM/avrXccFM) race 1 & + & + & + & $\varnothing$ \\
\hline 6181 race 0 & + & + & + & + \\
\hline $\mathrm{X} 83(6181 / a v r X c c F M)$ race ? & + & + & + & $(+)$ \\
\hline $3849 \mathrm{~A}$ race 2 & + & + & $\varnothing$ & + \\
\hline $\mathrm{X} 54(3849 \mathrm{~A} / a v r X c c F M)$ race? & + & + & $\varnothing$ & $\varnothing$ \\
\hline
\end{tabular}

a $+=$ typical black rot symptoms; $(+)=$ reduced symptoms; $\varnothing=$ null response. 
any combination, affected the nonhost HR elicited by $528^{\mathrm{T}}$ on pepper plants (Table 2).

A few putative non- $a v r$ effector genes have been identified in $528^{\mathrm{T}}$, based on sequence similarity to Ralstonia, Pseudomonas, and Xanthomonas type III secreted proteins, but only one has some experimental support as an effector in Xanthomonas spp. This ORF, classified as psvA (Xcc2896) by da Silva and associates (2002), is $71 \%$ identical to $x o p D$ from $X$. campestris pv. vesicatoria. Since $x o p D$ was shown to be secreted by the type III system and also to have small ubiquitin-like modifier proteolytic activity (Noel et al. 2002; Roden et al. 2004b), this gene was also included in the present study. However, interruption of the $x o p D$ homolog in $528^{\mathrm{T}}$ alone or in combination with up to seven of the $X$. campestris pv. campestris avr genes (Tables 1 and 2) also did not reveal any effect on $528^{\mathrm{T}}$ pathogenicity.

$a v r X c c F M$ functioned for avirulence. Mutations of this gene in $528^{\mathrm{T}}$, which is avirulent on Florida Mustard, enabled the mutants to become virulent on that differential host. $a v r X c c F M$ is among three $a v r$ genes identified in $528^{\mathrm{T}}$ as likely acquired by horizontal gene transfer (Garcia-Vallvé et al. 2003). When $a v r X c c F M$ was transferred to strains from two other races of $X$. campestris pv. campestris that are virulent on Florida Mustard, the bacteria became either completely avirulent, as in the case of race 2 strain 3849A, or somewhat avirulent, as in the case of race 0 strain 6181 (Table 3; Figs. 6 and 7). The visible although much smaller lesions observed in the latter case might be due to i) poor gene expression of $a v r X c c F M$ in strain 6181 ; ii) a defense suppression mechanism specific to 6181, or iii) lack of a chaperone-like protein or an imperfectly functioning chaperonelike protein required for delivering $a v r X c c F M$ into the host. Chaperone-like proteins have been identified as important secretion cofactors for some Avr effectors and can enhance their delivery to the host and the subsequent defense response (Alfano and Collmer 2004; Buttner et al. 2004).

Despite conferring avirulence to $X$. campestris pv. campestris strains on Florida Mustard, $a v r X c c F M$ did not elicit an obvious

Table 4. Primers and conditions used in this study

\begin{tabular}{|c|c|c|c|c|}
\hline Number & Sequence $^{\mathrm{a}}$ & Time & Gene & Ex. time ${ }^{b}$ \\
\hline \multicolumn{5}{|c|}{ For marker interruption } \\
\hline $\mathrm{AC}-5$ & GGAATTCAGAATAGGAACCTTCAATTCATGGGCAGGAAGCGCACTG & $>72$ & 1629 & $30 \mathrm{~s}$ \\
\hline AC-6 & GGGATCCAGTATAGGAACTTCTCTGAATCCGTTTGTCCTGTCCAG & $>72$ & 1629 & $30 \mathrm{~s}$ \\
\hline $\mathrm{AC}-23$ & GGATCCATGATGAGAGACTGCATGTAC & 68 & 2099 & $30 \mathrm{~s}$ \\
\hline AC-24 & GAGCTCTGACCGTTCATTACGAAATTC & 68 & 2099 & $30 \mathrm{~s}$ \\
\hline AC-29 & $\overline{\text { GGATCCACGCTGCATGACATTGTC }}$ & 66 & 2100 & $30 \mathrm{~s}$ \\
\hline $\mathrm{AC}-30$ & GAGCTCATTTCACGGATATGACTTCC & 66 & 2100 & $30 \mathrm{~s}$ \\
\hline $\mathrm{AC}-27$ & $\overline{\text { GGATCCAAGGAACTGCTACAACTATC }}$ & 66 & 2109 & $30 \mathrm{~s}$ \\
\hline AC-28 & 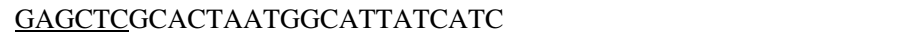 & 68 & 2109 & $30 \mathrm{~s}$ \\
\hline AC-25 & $\overline{\text { GGCATCCAGTTCTACAGCGGCGG }}$ & 68 & 2396 & $30 \mathrm{~s}$ \\
\hline AC-26 & GAGCTCAGCGGCGTCAACGG & 68 & 2396 & $30 \mathrm{~s}$ \\
\hline AC-19 & GTTAACGTGGAGCGGATCCATG & 68 & 3731 & $30 \mathrm{~s}$ \\
\hline $\mathrm{AC}-20$ & GAGCTCACATAGAGCACGTCAGAG & 70 & 3731 & $30 \mathrm{~s}$ \\
\hline AC-17 & CCACCTGGATCCGGGCTTCG & 68 & 4229 & $30 \mathrm{~s}$ \\
\hline AC- 18 & GAGCTCAGGGTCACGCTCCACG & 68 & 4229 & $30 \mathrm{~s}$ \\
\hline $\mathrm{AC}-\mathrm{C} 1$ & 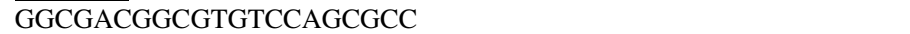 & $>72$ & 4229 & $30 \mathrm{~s}$ \\
\hline AC-C2 & GTGTAGTCCCAGTTGACGTTGC & 68 & 4229 & $30 \mathrm{~s}$ \\
\hline AC-60 & TGGCCGCGAATTCGACCTCAAC & 68 & 2896 & $30 \mathrm{~s}$ \\
\hline AC-61 & CGACGACGAGCAATGACCAATGAAAGT & $>72$ & 2896 & $30 \mathrm{~s}$ \\
\hline \multicolumn{5}{|c|}{ For interruption confirmation } \\
\hline AC-13 & GCAGGCGGCCTACCAGCTTG & 68 & 1629 & $1 \mathrm{~min}$ \\
\hline $\mathrm{AC}-14$ & TGCGCGGCGAAATGGGCTGC & 68 & 1629 & $1 \mathrm{~min}$ \\
\hline $\mathrm{AC}-15$ & GGTCATCATCTGCCCGCCATG & 68 & 1629 & $1 \mathrm{~min}$ \\
\hline AC-37 & ATGTCAATGGAGCGGGAGATGG & 68 & 2099 & $1 \mathrm{~min}$ \\
\hline AC-43 & TTATGCATTGTGGTCGAGCCATTC & 70 & 2099 & $1 \mathrm{~min}$ \\
\hline AC-49 & GCGAGCGCGGCAGGACTAC & 66 & 2099 & $1 \mathrm{~min}$ \\
\hline AC-50 & CCAGCAAGGTGGTGCAATCGG & 68 & 2099 & $1 \mathrm{~min}$ \\
\hline $\mathrm{AC}-34$ & ATGTCCGACATGAAAGTTAATTTCTG & 70 & 2100 & $1 \mathrm{~min}$ \\
\hline AC- 41 & TTACGCTTCTCCTGCATTTGTAAC & 68 & 2100 & $1 \mathrm{~min}$ \\
\hline AC- -35 & ATGTGGTCTCAGCCCGTATGG & 66 & 2109 & $1 \mathrm{~min}$ \\
\hline AC-39 & TTAGGATAATCAGCCACAAATTGG & 66 & 2109 & $1 \mathrm{~min}$ \\
\hline $\mathrm{AC}-45$ & CTGCAGTTTTTGTACGAATCCCTACCGATC & 68 & 2109 & $1 \mathrm{~min}$ \\
\hline AC-36 & GTGCTGGAGAGTGCCGATGGC & 70 & 2396 & $1 \mathrm{~min}$ \\
\hline AC- -44 & GTGAGACCACAGTGAATCGCC & 66 & 2396 & $1 \mathrm{~min}$ \\
\hline AC-32 & GTGGTGGCGGCCCAGAATCAC & 66 & 3731 & $1 \mathrm{~min}$ \\
\hline AC-48 & TTAGCTCCAGTACTCGGCGTC & 66 & 3731 & $1 \mathrm{~min}$ \\
\hline AC-33 & TGCCCGAGCGCCCTCATGC & 66 & 4229 & $1 \mathrm{~min}$ \\
\hline AC-42 & AGTTCCAGATCGCCACGCACC & 68 & 4229 & $1 \mathrm{~min}$ \\
\hline FW-XopD & ATGGAATATATACCAAGATA & 50 & 2896 & $1 \mathrm{~min}$ \\
\hline RV-XopD & CTAGAACTTTTTCCACCACTT & 58 & 2896 & $1 \mathrm{~min}$ \\
\hline \multicolumn{5}{|c|}{ For splice overlap PCR } \\
\hline $52-\mathrm{A} 1$ & CGCTGGCCGCCGAATGGATG & 68 & 52 & $1 \mathrm{~min}$ \\
\hline $52-\mathrm{F}$ & TCATACGCGTTCAGATCTTACTGTTCTAGCGCAGGCGATG & 60 & 52 & $1 \mathrm{~min}$ \\
\hline $52-\mathrm{C}$ & TAAGATCTGAACGCGTATGAGCAGACCATTCGCACGATG & 60 & 52 & $1 \mathrm{~min}$ \\
\hline 52-D1 & CCGATGGATCTATTGTTCTTCG & 64 & 52 & $1 \mathrm{~min}$ \\
\hline
\end{tabular}

\footnotetext{
${ }^{a}$ Underlined sequences indicate restriction enzyme sites or homology regions added for splice overlap PCR. Unless otherwise indicated, all primer sequences from $5^{\prime}$ to $3^{\prime}$.

${ }^{\mathrm{b}}$ Polymerase chain reaction (PCR) extension time used.

${ }^{\mathrm{c}} \mathrm{NA}=$ not applicable.

${ }^{\mathrm{d}} \mathrm{V}=$ variable time.
} 
HR in any $X$. campestris pv. campestris strain tested on Florida Mustard leaves. Florida Mustard leaves are capable of an obvious HR, since they exhibited a typical HR response to wild-type $X$. campestris pv. armoraciae, beginning $48 \mathrm{~h}$ after inoculation, that was coincident with electrolyte leakage (Fig. 4). Resistance to bacterial plant pathogens is not always associated with an obvious HR (Balague et al. 2003). More specifically, resistance of Brassica plants to $X$. campestris pv. campestris is not (usually) associated with an obvious HR (Buell 2002; Buell and Somerville 1997). Kamoun and associates (1992) proposed that resistance to X. campestris pv. campestris is not associated with a mesophyllic HR but is associated with a more difficult-to-detect vascular HR. Significantly, avrXccFM appeared responsible for eliciting the vascular HR in seedlings inoculated with $528^{\mathrm{T}}$, since mutants at the locus lost such ability and $a v r X c c F M$ complemented the mutations. This observation is therefore consistent with the hypothesis that an HR occurs in leaves but is limited to cells surrounding vascular tissue (Bretschneider et al. 1989; Kamoun et al. 1992).
$X$. campestris pv. campestris was proposed to be comprised of five races, based on disease reactions using four differential varieties in three species: Early Jersey Wakefield cabbage $(B$. oleracea), Just Right turnip and Seven Top Green turnip ( $B$. rapa), and Florida Broadleaf Indian Mustard (B. juncea) (Kamoun et al. 1992). Vicente and associates (2001) proposed a new race structure for $X$. campestris pv. campestris defined by two additional host differentials, PI199947 (B. carinata) and Miracle F1 (B. oleracea). However, we could not reproduce the proposed race reactions on these additional differentials and therefore used the original system of Kamoun and associates (1992). It is possible that some varietal variation exists within PI199947 and Miracle F1.

Ignatov and associates (2003) suggested that an avrBs 2 homolog determines avirulence of $X$. campestris pv. campestris $512 / 2$ on Brassica plants with the B genome, specifically, both Florida Mustard and PI199947, and was also responsible for a mesophyllic HR on leaves of both Florida Mustard and nonhost pepper plants carrying $B s 2$. However, our analy-

Table 4. (Continued from preceding page)

\begin{tabular}{|c|c|c|c|c|}
\hline Number & Sequence $^{\mathrm{a}}$ & Time & Gene & Ex. time \\
\hline \multicolumn{5}{|c|}{ For splice-overlap PCR (Continued) } \\
\hline 2099-A & GGAATTCTCGATGACCTGCTCCAACG & $>72$ & 2099,2100 & $1 \mathrm{~min}$ \\
\hline 2099-B & TCATACGCGTTCAGATCTTACATCTATGGGGCCTGTTCG & 60 & 2099,2100 & $1 \mathrm{~min}$ \\
\hline 2099-C & TAAGATCTGAACGCGTATGAAGAGAAGAAGTATCCGCCAC & 60 & 2099,210 & $1 \mathrm{~min}$ \\
\hline 2099-D & 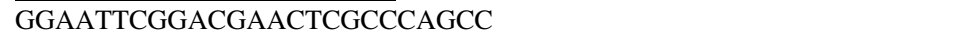 & $>72$ & 2099,2100 & $1 \mathrm{~min}$ \\
\hline 2109-A & TTTGTCGAGCGAGCGTCAC & 60 & 2109 & $1 \mathrm{~min}$ \\
\hline 2109-B & TCATACGCGTTCAGATCTTACCAATTTGTGGCTGATTATCC & 60 & 2109 & $1 \mathrm{~min}$ \\
\hline 2109-E & TAAGATCTGAACGCGTATGAGTCCGAAATCTGGTGAAGAG & 60 & 2109 & $1 \mathrm{~min}$ \\
\hline 2109-F & $\overline{\text { GTGAGTTCGGCCTACAACCA }}$ & 62 & 2109 & $1 \mathrm{~min}$ \\
\hline 2396-A1 & GCTGATCTGGAAGTTGTAGG & 60 & 2396 & $1 \mathrm{~min}$ \\
\hline 2396-B & TCATACGCGTTCAGATCTTATACCTGCTGATGCACATGTC & 60 & 2396 & $1 \mathrm{~min}$ \\
\hline 2396-C & $\overline{\text { TAAGATCTGAACGCGTATGA GGTCGTGCAAGTGGGCAGTGG }}$ & 60 & 2396 & $1 \mathrm{~min}$ \\
\hline 2396-D & GCAGTGCGGATGGCAGCC & 62 & 2396 & $1 \mathrm{~min}$ \\
\hline 4229-A & GGCGTTTTCCATGCTGATGTAC & 66 & 4229 & $1 \mathrm{~min}$ \\
\hline 4229-B & TCATACGCGTTCAGATCTTAGCAGGCGGCGGGGCAATGCAGGC & 60 & 4229 & $1 \mathrm{~min}$ \\
\hline 4229-C & TAAGATCTGAACGCGTATGAGCCGATCAACAGCCTGCGCTC & 60 & 4229 & $1 \mathrm{~min}$ \\
\hline 4229-D & $\overline{\text { CGCGTGGTCGACTGACAACG }}$ & 66 & 4229 & $1 \mathrm{~min}$ \\
\hline \multicolumn{5}{|c|}{ For deletion confirmation } \\
\hline $52-\mathrm{E}$ & GCTGGATCTGATCCGCAGT & 60 & 52 & $1 \min 30 \mathrm{~s}$ \\
\hline $52-\mathrm{H}$ & CCTGGGTGGACCACGATGTG & 66 & 52 & $1 \min 30 s$ \\
\hline 2099-A1 & GTGCTGCGCTGATGTATTCGG & 66 & 2099,2100 & $2 \mathrm{~min}$ \\
\hline 2099-D1 & AAGACAAGAGCGACCAACACC & 64 & 2099,2100 & $2 \mathrm{~min}$ \\
\hline 2109-A1 & GCAATCGAGGTATCGTCATG & 60 & 2109 & $1 \min 30 \mathrm{~s}$ \\
\hline 2109-F & GTGAGTTCGGCCTACAACCA & 62 & 2109 & $1 \min 30 s$ \\
\hline 2396-A1 & GCTGATCTGGAAGTTGTAGG & 60 & 2396 & $1 \min 30 \mathrm{~s}$ \\
\hline 2396-D1 & CCGTACTACCGCCATGCC & 60 & 2396 & $1 \min 30 s$ \\
\hline 4229-A1 & AATCGGCGAACTCGTTGTTG & 60 & 4229 & $1 \min 30 s$ \\
\hline 4229-D1 & CTCCGGGCGCACCATCCAGATC & 74 & 4229 & $1 \mathrm{~min} 30 \mathrm{~s}$ \\
\hline \multicolumn{5}{|c|}{ For $f l p$ recognition target (FRT) plasmid construction } \\
\hline FRTKn-F & GAATTCGCTGCTTCGAAGTTCCTATAC & 62 & $\mathrm{NA}^{\mathrm{c}}$ & $1 \min 30 \mathrm{~s}$ \\
\hline FRTKn-R & 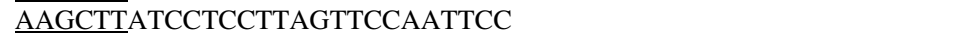 & 60 & NA & $1 \min 30 s$ \\
\hline \multicolumn{5}{|c|}{ For complementation assays } \\
\hline 9.03 & GAATTCCATGGGTCTATGCGCTTCAAAACC & 68 & 2109 & $1 \min 30 \mathrm{~s}$ \\
\hline 9.04 & GAATTCCAGGAGATCGACATGGGTCTATG & 70 & 2109 & $1 \min 30 \mathrm{~s}$ \\
\hline AC-35 & ATGTGGTCTCAGCCCGTATGG & 66 & 2109 & $1 \mathrm{~min} 30 \mathrm{~s}$ \\
\hline AC-45 & CTGCAGTTTTTGTACGAATCCCTACCGATC & 68 & 2109 & $1 \min 30 \mathrm{~s}$ \\
\hline \multicolumn{5}{|l|}{ For SacB cloning } \\
\hline $\mathrm{SAC}-\mathrm{C} 2$ & CACGTAGTGATATGGATGACGGATG & 70 & $\mathrm{SacB}$ & $1 \mathrm{~min}$ \\
\hline SAC-D2 & CACTACGTGAAATGAGATATTATGATATTTTC & 70 & $\mathrm{SacB}$ & $1 \mathrm{~min}$ \\
\hline \multicolumn{5}{|c|}{ For suppression subtractive hybridization (SSH) } \\
\hline Adaptor 1 & $\begin{array}{l}\text { CTAATACGACTCACTATAGGGCTCGAGCGGCCGCCCGGGAGGT3'- } \\
\text { GGCCCGTCCA-5 }\end{array}$ & SSH & NA & NA \\
\hline Adaptor $2 \mathrm{R}$ & $\begin{array}{l}\text { CTAATACGACTCACTATAGGGCAGCGTGGTCGCGGCCGAGGT3'GCCGGC } \\
\text { TCCA5' }\end{array}$ & SSH & NA & NA \\
\hline Primer 1 & CTAATACGACTCACTATAGGGC & SSH & NA & \\
\hline Nested primer $1 \mathrm{R}$ & TCGAGCGGCCGCCCGGGCAGGT & SSH & NA & NA \\
\hline Nested primer $2 \mathrm{R}$ & AGCGTGGTCGCGGCCGAGGT & SSH & NA & NA \\
\hline \multicolumn{5}{|l|}{ Vector-based primers } \\
\hline M13R(-48) & AGCGGATAACAATTTCACACAGGA & 64 & Vector based & $\mathrm{V}^{\mathrm{d}}$ \\
\hline M13(-47) & GCCAGGGTTTTCCCAGTCACG & 64 & Vector based & V \\
\hline JR2 & ACGATCGGTTCGCCAGCCAGGAC & 54 & $\mathrm{Gm}^{\mathrm{r}}$ & $1 \mathrm{~min}$ \\
\hline
\end{tabular}


sis showed that deletion of the entire putative $a v r B s 2$ homolog Xcc0052 (Fig. 2; Table 2) in X. campestris pv. campestris $528^{\mathrm{T}}$ i) had no effect on avirulence in Florida Mustard (i.e., all Xcc0052 knockout strains remained avirulent) and ii) had no effect on the nonhost HR in any of the four different pepper cultivars inoculated (i.e., all Xcc0052 knockout strains elicited an HR), including ECW-20R (carrying Bs2). Furthermore, wild-type $528^{\mathrm{T}}$ was virulent on PI199947 (data not shown), and we did not detect a mesophyllic HR in leaves of Florida Mustard either visually or using electrolyte leakage, using wild-type $528^{\mathrm{T}}$. It is possible that strain $512 / 2$ carries an active $a v r B s 2$ homolog and $528^{\mathrm{T}}$ did not. If so, by genefor-gene theory, Florida Mustard would carry at least two resistance genes against $X$. campestris pv. campestris ( $F M$ and $B s 2$ or functional equivalent) and $512 / 2$ would not carry avrXccFM. This hypothesis is testable.

Of the eight putative $528^{\mathrm{T}}$ avr genes and putative $x o p D$ effector gene experimentally investigated here, only avrXccFM appeared to be phenotypically functional. There are a number of possible explanations for this. First, it is possible that some or all of the $a v r$ effectors are pseudogenes or poorly expressed. Second, these genes may encode proteins with defective secretion signals and so fail to be recognized by the type III secretion system or by a required chaperone; at least some effectors appear to require chaperones for secretion (Alfano and Collmer 2004). Third, it is possible that some of these genes were horizontally acquired without their chaperones and so fail to be secreted. However, these explanations seem generally unlikely for all eight $a v r$ genes.

It is argued that assays conducted in growth chambers may not be sensitive enough to detect additive $a v r$ gene contributions to pathogenicity or not done in the right context to detect $a v r$ gene effects on ecological fitness (Chang et al. 2004). For example, although mutation of avrBs 2 in $X$. axonopodis pv. vesicatoria had a major effect on pathogenicity and the mutation of three additional avr genes in the same strain had no detected effect on pathogenicity in growth-chamber tests, field tests revealed statistically significant, additive effects of the three additional $a v r$ genes on ecological fitness (Wichmann and Belgerson 2004). However, the converse is also true; pathogenicity assays in growth chambers may not be sensitive enough to detect negative effects on pathogenicity or on ecological fitness, such as the reduced survival in soil conferred by avrBsl to $X$. axonopodis pv. vesicatoria (O'Garro et al. 1997). In the experiments reported here, all eight of the putative avr genes identified in the $X$. campestris pv. campestris genome were disrupted or removed, including avrBs2, leaving none behind. While it is possible that some of these genes may contribute to reduced or increased ecological fitness in the field, they had no detected effect, even additively, on in planta growth or pathogenicity.

Clearly, since hrp system knockouts in X. campestris pv. campestris are completely nonpathogenic in growth chamber tests (Kamoun et al. 1992), the type III effectors primarily responsible for $X$. campestris pv. campestris systemic pathogenicity are not among the eight $a v r$ gene homologs identified to date. Besides the eight avr effectors and xopD examined in this study, eight additional putative effector genes were identified in $528^{\mathrm{T}}$ that remain to be functionally tested. These include two leucine-rich proteins having PIP boxes (Xcc2565 and Xcc4186; da Silva et al. 2002) and six genes identified as type III-secreted (Xcc1072, Xcc1089, Xcc1246, Xcc1247, Xcc3258, and Xcc3600; Roden et al. 2004a; Rohmer et al. 2004; Genin and Boucher 2004).

Since the type III secretion machine is indiscriminate, secreting all available effectors with a type III signal into both host and nonhost cells alike (Jin et al. 2003; Rossier et al. 1999;
Silhavy 1997), horizontal transfer of effector genes should result in the accumulation in any given pathogenic strain of genes or gene relics annotated as effector homologs. Given the high degree of host specificity of type III effectors, relatively recent horizontal transfer events should result in gratuitous, out-of-context effectors (Gabriel 1999). Unadapted type III effectors should be either generally detrimental (O'Garro et al. 1997) or detrimental in specific contexts, as are all avirulence genes, by definition. Adaptation, if any, of detrimental genes to new host or pathogen contexts should often result simply in loss-of-function mutations, which may have occurred with some or all of the remaining seven of the annotated $528^{\mathrm{T}} a v r$ gene homologs investigated in this study.

\section{MATERIALS AND METHODS}

Plasmids, bacterial strains, and culture conditions.

Bacterial strains and plasmids used or constructed in this study are listed in Table $1 . X$. campestris pv. campestris strains were grown in PYGM at $30^{\circ} \mathrm{C}$ (De Feyter et al. 1990), and Escherichia coli strains were grown at $37^{\circ} \mathrm{C}$ in Luria-Bertani (LB) medium (Maniatis et al. 1982). When appropriate, antibiotics were used at the following concentrations $(\mu \mathrm{g} / \mathrm{ml})$ : ampicillin (Ap), 50; gentamicin (Gm), 5; kanamycin (Kn), 12.5 for xanthomonads or 20 for E. coli; rifampicin (Rif), 75; and chloramphenicol $(\mathrm{Cm}), 35$. When needed, sucrose was added to a final concentration of $5 \%$.

\section{SSH.}

The PCR select bacterial genome subtraction kit, (Clontech Laboratories, Inc., Palo Alto, CA, U.S.A.) was used according to the manufacturer's instructions, with the following modifications. $528^{\mathrm{T}}$ and 417 genomic DNA were extracted using the Genomic prep kit (Amersham Biosciences, Piscataway, NJ, U.S.A.). Approximately $2 \mu \mathrm{g}$ of both $528^{\mathrm{T}}$ and 417 genomic DNA were digested with $15 \mathrm{U}$ of $R s a \mathrm{I}$ for $16 \mathrm{~h}$. Half of the DNA from $528^{\mathrm{T}}$ was ligated to adaptor 1 and the other half to adaptor $2 \mathrm{R}$ as recommended. Digested 417 DNA was mixed with each of the $528^{\mathrm{T}}$ ligated adaptor DNAs in separate tubes, and the samples were hybridized at $63^{\circ} \mathrm{C}$. Amplification of the SSH product was performed with nested primer 1 (Table 4) at $61^{\circ} \mathrm{C}$ for 35 cycles, and the second round of amplification was performed with nested primer $2 \mathrm{R}$ at $61^{\circ} \mathrm{C}$ for 25 cycles.

DNA from the second PCR amplification mix (3 $\mu \mathrm{l})$ was ligated into pGEMTeasy (Promega Co., Madison, WI, U.S.A.) according to the manufacturer's instructions, were transformed into DH5 $\alpha$ cells, and were plated on LB plus Ap.

\section{Xanthomonas electroporation.}

Overnight liquid Xanthomonas broth cultures in PYGM medium were grown at $28^{\circ} \mathrm{C}$ to mid-exponential growth phase (optical density at $600 \mathrm{~nm}\left(\mathrm{OD}_{600}\right)=0.5$ to 0.6 ). Cells were incubated on ice for $30 \mathrm{~min}$ and were collected by centrifugation at $4,000 \times g$ at $4^{\circ} \mathrm{C}$. Cell pellets were washed three times with approximately $10 \mathrm{ml}$ of chilled sterile distilled water and were collected as before. Cells were then resuspended in 160 $\mu \mathrm{l}$ of sterile, ice-cold $10 \%$ glycerol, and $40 \mu \mathrm{l}$ of cells were electroporated immediately or were aliquoted and stored at $80^{\circ} \mathrm{C}$. Approximately $250 \mathrm{ng}$ of plasmid DNA was electroporated into $40 \mu \mathrm{l}$ of electrocompetent Xanthomonas cells at 18 $\mathrm{kV} / \mathrm{cm}$, using an Eppendorf 2510 electroporator (Westbury, NY, U.S.A.). Following electroporation, $960 \mu$ of liquid PYGM was added to the mix, the culture was grown at $30^{\circ} \mathrm{C}$ for 2 to $3 \mathrm{~h}$ at $120 \mathrm{rpm}$, and the entire amount was spread onto PYGM plates containing an appropriate antibiotic for selection of the introduced plasmid. 


\section{Site directed and serial mutagenesis}

Marker interruption, $f l p$ recognition target (FRT) interruption, and splice-overlap PCR (marker deletion) mutagenic methods (Fig. 1) were used to create individual and serial mutations in the $528^{\mathrm{T}}$ genome following electroporation. Primers used were synthesized by Integrated DNA Technologies (Coralville, IA, U.S.A.) and are listed in Table 4.

For marker interruption (Fig. 1A), an internal region of the target gene was PCR-amplified, using a single colony touched with a toothpick and swirled into the PCR mix as the source of template DNA. Reactions $(25 \mu \mathrm{l})$ were performed using Invitrogen (Carlsbad, CA, U.S.A.) Taq polymerase and PCR buffer according to instructions, with each primer at a final concentration of $0.4 \mu \mathrm{M}$. The initial denaturation step was at $95^{\circ} \mathrm{C}$ for $3 \mathrm{~min}$, followed by 35 cycles of $30 \mathrm{~s}$ at $95^{\circ} \mathrm{C}$, $30 \mathrm{~s}$ at the specified annealing temperature, $70^{\circ} \mathrm{C}$ for the specified extension time, with a final $10 \mathrm{~min}$ extension at $70^{\circ} \mathrm{C}$. The PCR reaction $(1 \mu \mathrm{l})$ was used for cloning into TOPO vector (Invitrogen Corp., Carlsbad, CA, U.S.A.), using the manufacturer's protocol and, except for the XopD homolog, in which the internal region was cloned into TOPO and used directly for interruption, the insert was recloned into pAC7, pAC3.1, or pUFR12 and was used for electroporation into $528^{\mathrm{T}}$ or mutant derivatives. Colonies that grew on PYGM plus Kn were transferred to PYGM plus $\mathrm{Cm}$ plates to confirm vector integration. Those that were resistant to both antibiotics were then tested by PCR and Southern hybridization to verify that the target gene was disrupted. For marker interruption using TOPO, the colonies that grew on PYGM plus Kn were PCR-tested immediately.

For FRT interruption (Fig. 1B), a simplified variation on the method of Hoang and associates (1998) was used. An internal region of the target gene was PCR-amplified using the appropriate primers (Table 4) and was cloned into TOPO, recloned into pBY17.1, and electroporated into 528T. Marker interrupted mutant strains of $528^{\mathrm{T}}$ were first selected on PYGM plus $\mathrm{Kn}$, followed by screening on PYGM plus $\mathrm{Cm}$, and then were analyzed by PCR using both vector- and fragment-based primers. Positive colonies were selected and then were again electroporated with $50 \mathrm{ng}$ of pJR4, were plated onto PYGM plus Gm, and then, were grown in sucrose to evict the integrated suicide vector. The resulting colonies were replica-plated onto PYGM plus sucrose to induce curing of pJR4, and colonies growing only on sucrose without $\mathrm{Kn}$ were selected for screening by PCR and Southern hybridization.

For splice overlap PCR (Fig. 1C; Horton et al. 1989), two regions approximately $1 \mathrm{~kb}$ long, upstream and downstream of the target gene, were independently PCR-amplified with their respective primer sets $a, b$ and $c, d$ using Fail Safe PCR premix D (Epicenter Technologies, Madison, WI, U.S.A.) and PCR conditions as described above. Both PCR products were diluted 1:25, $1 \mu$ l of each were mixed together, and a fill-in reaction was done in the same buffer $\left(95^{\circ} \mathrm{C}\right.$ for $3 \mathrm{~min}$, $50^{\circ} \mathrm{C}$ for $1 \mathrm{~min}$, and $70^{\circ} \mathrm{C}$ for $5 \mathrm{~min}$ ) using $\mathrm{Taq}$ polymerase. External primers (Fig. 1C, a and d) were then added at 0.4 $\mu \mathrm{M}$ each to the reaction, and 35 cycles of PCR were performed as before. This reaction $(1 \mu \mathrm{l})$ was cloned directly into TOPO or the desired band was gel-purified using the QIAquick gel extraction kit (Qiagen, Valencia, CA, U.S.A.) and was cloned into TOPO. The resulting plasmids were transformed in DH5 $\alpha$ cells. Inserts of the correct size were recloned into pUFR080 and were sequenced and electroporated into $528^{\mathrm{T}}$ or mutant derivatives. Colonies with plasmid integration at one of the $528^{\mathrm{T}}$ target sites were selected on PYGM plus Kn plates and were subsequently confirmed on PYGM plus $\mathrm{Cm}$ plates. These were grown in liquid PYGM overnight, the $\mathrm{OD}_{600}$ was adjusted to 0.13 , and $20 \mu \mathrm{l}$ were spread onto
PYGM containing sucrose and Rif. Colonies that grew on sucrose were replica-plated onto PYGM plus $\mathrm{Kn}$ and sucrose, and colonies growing only on sucrose plates without $\mathrm{Kn}$ were selected and analyzed by PCR and Southern hybridization. Probes used for Southern hybridizations were PCR products cloned in TOPO or pUFR080.

\section{DNA sequencing and analysis.}

All DNA sequencing was performed by the ICBR (Interdisciplinary Center for Biotechnology Research) DNA Sequencing Core Facility at the University of Florida. All $528^{\mathrm{T}}$ DNA clones resulting from SSH were sequenced. To confirm that the cloned DNA fragments were unique to $528^{\mathrm{T}}$, the $\mathrm{SSH}$ clones were PCR-amplified with vector-based primers M13R $(-48)$ and M13 (-47). Each PCR amplification product $(2 \mu \mathrm{l})$ was spotted twice with a replicator (VP408S2a; V \& P Scientific Inc., San Diego, CA, U.S.A.) on two different nylon membranes and also was run on $1 \%$ agarose gels to confirm that the amplified products were uniform in concentration.

Total $R s a$ I-digested $528^{\mathrm{T}}$ and 417 DNA (500 ng) were separately labeled with ${ }^{32} \mathrm{P}$, using the Random primer kit II (Stratagene, La Jolla, CA, U.S.A.) according to the manufacturer's protocol. The two labeled DNA samples were used as a probe with each of the corresponding membranes. Clones of interest were further confirmed as $528^{\mathrm{T}}$ specific by Southern hybridization analyses.

\section{Plant inoculation assays.}

All plants were grown under greenhouse conditions. Leaves from 3-week-old cabbage Early Jersey Wakefield (B. oleracea var. capitata; Sawan Seed Co., Pelham, GA, U.S.A.), Seven Top Turnip (B. rapa; Sieger Seed Co., Zeeland, MI, U.S.A.), Sparkler Radish ( $R$. sativa; Excel Seeds, Camp Point, IL, U.S.A.), Florida Broadleaf Indian Mustard (B. juncea; Sieger Seed Co.), white turnip Hakurei Hybrid (B. rapa; Ferry-Morse Seed Co. Phoenix, AZ, U.S.A.), PI199947 (B. carinata), cauliflower Miracle F1 (B. oleracea var. botrytis), and A. thaliana ecotypes Coimbra-1 and Columbia- 0 were inoculated at two concentrations.

Xanthomonas cultures were grown overnight in liquid PYGM, and then, were centrifuged at $5,000 \times g$ for $5 \mathrm{~min}$, were washed with sterile tap water, and were adjusted to $\mathrm{OD}_{600}=0.3$ (approximately $10^{8} \mathrm{CFU} / \mathrm{ml}$ ). A 1:1,000 dilution of this suspension was made for low-concentration inoculations (approximately $10^{5} \mathrm{CFU} / \mathrm{ml}$ ). For each inoculation, $2 \mathrm{~cm}$ on each side of each leaf was cut with scissors that had been dipped in the appropriate bacterial suspension. Scissors were flame-sterilized between inoculations. For HR screening, cultures at an $\mathrm{OD}_{600}=$ 0.3 were pressure-infiltrated using the blunt end of a tuberculin syringe into the abaxial leaf surface. After inoculation, plants were maintained in a standard growth chamber equipped with fluorescent and incandescent lights for $16 \mathrm{~h}$ at $28^{\circ} \mathrm{C}$, followed by $8 \mathrm{~h}$ of dark at $27^{\circ} \mathrm{C}$ for up to 14 days. Pathogenic symptoms were scored daily. HR symptoms were scored every hour, from 12 to $36 \mathrm{~h}$ after inoculation. At least three plants were inoculated in each experiment. All experiments were reproduced at least two times.

For seedling assays, Florida Mustard seeds were grown under continuous light in growth chambers at $29^{\circ} \mathrm{C}$. Seven-day-old plants were inoculated by pricking the hypocotyls with a 25gauge syringe needle that was dipped into a bacterial colony (Kamoun et al. 1992). Plants were observed starting at $16 \mathrm{~h}$ and for up to 5 days.

For the nonhost HR, pepper plants ECW, ECW-10R, ECW20R, and ECW-30R (Capsicum annum) were inoculated by pressure infiltration, using the blunt end of a tuberculin syringe into the abaxial leaf surface at four serially diluted concentra- 
tions $\left(10^{8}, 10^{7}, 10^{6}\right.$, and $\left.10^{5} \mathrm{CFU} / \mathrm{ml}\right)$ and were observed at 18 , 24,36 , and $48 \mathrm{~h}$ after inoculation. HR symptoms were scored every hour, from 12 to $36 \mathrm{~h}$ after inoculation. At least three plants were inoculated in each experiment, and each experiment was repeated at least two times.

\section{Electrolyte leakage assays.}

Bacterial suspensions were diluted to a concentration of $1 \times$ $10^{5} \mathrm{CFU} / \mathrm{ml}$ in sterile tap water, and measurements were carried out exactly as described previously (Hibberd et al. 1987). Essentially, for each sample, six $0.5-\mathrm{cm}^{2}$ leaf disks were removed with a \#7 cork borer, were submerged in $3 \mathrm{ml}$ of distilled water, and were vacuum infiltrated, and the net leakage after $1 \mathrm{~h}$ was measured with a conductivity meter. Two samples were taken for each measurement in each experiment; the experiments were repeated three times.

\section{Growth kinetics.}

The abaxial leaf surface of fully expanded leaves from white turnip and Florida Mustard plants were syringe-infiltrated with $1 \times 10^{5} \mathrm{CFU} / \mathrm{ml}$ of inoculum. Each inoculation site was flooded to achieve a zone of approximately $0.5 \mathrm{~cm}$ in diameter. Samples were taken in triplicate with a \#14 cork-borer (2.2-cm diameter) to encompass the entire inoculation site starting at day 0 and then every two days until day 8 . The leaf tissue samples were macerated in $1 \mathrm{ml}$ of $100 \mu \mathrm{l}$ of Silwet L-77 (Osi Specialties Inc., Friendly, WV, U.S.A.) plus saturated $\mathrm{CaCO}_{3}$ in water, were serially diluted, and were plated on PYGM plates. Colonies were counted two days after plating.

\section{Complementation assays.}

Primers AC-35 and AC-45 (Table 4) were used to amplify ORF Xcc2109 (Xanthomonas-ONSA FAPESP network). Primers 09-04 and AC-45 were used to amplify a longer ORF that includes $X c c 2109$ and 327 bp upstream ( $a v r X c c F M)$, including the SD region of the gene. The two DNA sequences were cloned into TOPO and were recloned into pUFR070 to form pAC10 and pAC19, respectively. Correct orientation of both clones for expression from the $l a c Z$ promoter on pUFR070 was confirmed by sequencing, and approximately $50 \mathrm{ng}$ of DNA was electroporated into the individual Xcc2109 knockout mutants X48 and X109 (Table 1). Colonies appearing on appropriate selection media were grown in liquid PYGM supplemented with antibiotics. The cultures were centrifuged and washed with tap water, the concentration was adjusted to $10^{5}$ $\mathrm{CFU} / \mathrm{ml}$, and the suspension was inoculated into Florida Mustard leaves using scissors as described. Plants were scored one week after inoculation.

\section{Race specificity change.}

$X$. campestris pv. campestris 6181 and 3849A, representing races 0 and 2, respectively (Kamoun et al. 1992), were electroporated using pAC19 and pAC10 DNA and were selected on the appropriate antibiotics. Cultures were grown and inoculated in Florida Mustard, Early Jersey Wakefield cabbage, Just Right turnip, and Seven Top turnip plants as described for other strains of $X$. campestris pv. campestris. At least three plants were inoculated in each experiment, and each experiment was repeated at least twice.

\section{ACKNOWLEDGMENTS}

We wish to thank G. C. Marlow for maintaining the plants and for helping with some of the laboratory analyses. PI199947 (B. carinata) and Miracle F1 cauliflower (B. oleracea var. botrytis) were kindly provided by J. Jones, University of Florida, Gainesville. A. thaliana seeds were kindly provided by J. Rollins, University of Florida, Gainsville.

\section{LITERATURE CITED}

Abramovitch, R. B, Kim, Y. J., Chen, S., Dickman, M. B., and Martin, G. B. 2003. Pseudomonas type III effector AvrPtoB induces plant disease susceptibility by inhibition of host programmed cell death. EMBO (Eur. Mol. Biol. Organ.) J. 22:60-69.

Alfano, J. R., and Collmer, A. 2004. Type III secretion system effector proteins: Double agents in bacterial disease and plant defense. Annu. Rev. Phytopathol. 42:385-414.

Alvarez, A. M., Benedict, A. A., Mizumoto, C. Y., Hunter, J. E., and Gabriel, D. W. 1994. Serological, pathological, and genetic diversity among strains of Xanthomonas campestris infecting crucifers. Phytopathology 84:1449-1457.

Badel, J. L., Nomura, K., Bandyopadhay, S., Shimizu, R., Collmer, A., and Yang He, S. 2003. Pseudomonas syringae pv. tomato DC3000 HopPtoM (CEL ORF3) is important for lesion formation but not growth in tomato and is secreted and translocated by the Hrp type III secretion system in a chaperone-dependent manner. Mol. Microbiol. 49:12391251 .

Balague, C., Lin, B., Alcon, C., Flottes, G., Malmstrom, S., Kohler, C., Neuhaus, G., Pelletier, G., Gaymard, F., and Roby, D. 2003. HLM1, an essential signaling component in the hypersensitive response, is a member of the cyclic nucleotide-gated channel ion channel family. Plant Cell 15:365-379.

Black, L. L., and Machmud, M. 1983. Xanthomonas leaf spot of crucifers. Page 126 in: Fourth International Congress of Plant Pathology, Melbourne, Australia.

Bogdanove, A. J., Kim, J. F., Wei, Z., Kolchinsky, P., Charkowski, A. O., Conlin, A. K., Collmer, A., and Beer, S. V. 1998. Homology and functional similarity of an hrp-linked pathogenicity locus, dspEF, of $E r$ winia amylovora and the avirulence locus avrE of Pseudomonas syringae pathovar tomato. Proc. Natl. Acad. Sci. U.S.A. 95:1325-1330.

Bretschneider, K. E., Gonella, M. P., and Robeson, D. J. 1989. A comparative light and electron microscopical study of compatible and incompatible interactions between Xanthomonas-campestris pv. campestris and cabbage (Brassica-oleracea). Physiol. Mol. Plant Pathol. 34:285297.

Buell, C. R. 2002. Interaction between Xanthomonas species and Arabidopsis thaliana. In: The Arabidopsis Book. C. R. Somerville and E. M. Meyeerowitz, eds. American Society of Plant Biologists, Rockville, MD, U.S.A..

Buell, C. R., and Somerville, S. C. 1997. Use of Arabidopsis recombinant inbred lines reveals a monogenic and a novel digenic resistance mechanism to Xanthomonas campestris pv. campestris. Plant J. 12:21-29.

Buttner, D., Noel, L., Thieme, F., and Bonas, U. 2003. Genomic approaches in Xanthomonas campestris pv. vesicatoria allow fishing for virulence genes. J. Biotech. 106:203-214.

Buttner, D., Gurlebeck, D., Noel, L. D., and Bonas, U. 2004. HpaB from Xanthomonas campestris pv. vesicatoria acts as an exit control protein in type III-dependent protein secretion. Mol. Microbiol. 54:755-768.

Cunnac, S., Occhialini, A., Barberis, P., Boucher, C., and Genin, S. 2004. Inventory and functional analysis of the large Hrp regulon in Ralstonia solanacearum: Identification of novel effector proteins translocated to plant host cells through the type III secretion system. Mol. Microbiol. 53:115-128.

Chang, J. H., Goel, A. K., Grant, S. R., and Dangl, J. L. 2004. Wake of the flood: Ascribing functions to the wave of type III effector proteins of phytopathogenic bacteria. Curr. Opin. Microbiol. 7:11-18.

Chen, J., Roberts, P. D., and Gabriel, D. W. 1994. Effects of a virulence locus from Xanthomonas campestris 528T on pathovar status and ability to elicit blight symptoms on crucifers. Phytopathology 84:1458-1465.

Daniels, M. J., Dow, J. M., and Osbourn, A. E. 1988. Molecular genetics of pathogenicity in phytopathogenic bacteria. Annu. Rev. Phytopathol. 26:285-312.

da Silva, A. C., Ferro, J. A., Reinach, F. C., Farah, C. S., Furlan, L. R., Quaggio, R. B., Monteiro-Vitorello, C. B., Van Sluys, M. A., Almeida, N. F., Alves, L. M., do Amaral, A. M., Bertolini, M. C., Camargo, L. E., Camarotte, G., Cannavan, F., Cardozo, J., Chambergo, F., Ciapina, L. P., Cicarelli, R. M., Coutinho, L. L., Cursino-Santos, J. R., El-Dorry, H., Faria, J. B., Ferreira, A. J., Ferreira, R. C., Ferro, M. I., Formighieri, E. F., Franco, M. C., Greggio, C. C., Gruber, A., Katsuyama, A. M., Kishi, L. T., Leite, R. P., Lemos, E. G., Lemos, M. V., Locali, E. C., Machado, M. A., Madeira, A. M., Martinez-Rossi, N. M., Martins, E. C., Meidanis, J., Menck, C. F., Miyaki, C. Y., Moon, D. H., Moreira, L. M., Novo, M. T., Okura, V. K., Oliveira, M. C., Oliveira, V. R., Pereira, H. A., Rossi, A., Sena, J. A., Silva, C., de Souza, R. F., Spinola, L. A., Takita, M. A., Tamura, R. E., Teixeira, E. C., Tezza, R. I., Trindade dos Santos, M., Truffi, D., Tsai, S. M., White, F. F., Setubal, J. C., and Kitajima, J. P. 2002. Comparison of the genomes of two Xanthomonas pathogens with differing host specificities. Nature 417:459-463. 
Datsenko, K. A., and Wanner, B. L. 2000. One-step inactivation of chromosomal genes in Escherichia coli K-12 using PCR products. Proc. Natl. Acad. Sci. U.S.A. 97:6640-6645.

De Feyter, R., Kado, C. I., and Gabriel, D. W. 1990. Small stable shuttle vectors for use in Xanthomonas. Gene 88:65-72.

De Feyter, R., Yang, Y., and Gabriel, D. W. 1993. Gene-for-gene interactions between cotton $R$ genes and Xanthomonas campestris pv. malvacearum avr genes. Mol. Plant-Microbe Interact. 6:225-237.

Gabriel, D. W. 1999. Why do pathogens carry avirulence genes? Physiol. Mol. Plant Pathol. 55:205-214.

Gabriel, D. W. 2001. Bacterial avirulence genes. Pages 68-71 in: Encyclopedia of Plant Pathology. O. C. Maloy and T. D. Murray, eds. John Wiley \& Sons, New York.

Garcia-Vallvé, S., Guzmán, E., Montero, M. A., and Romeu, A. 2003. HGT-DB: A database of putative horizontally transferred genes in prokaryotic complete genomes. Nucl. Acids Res. 31:187-189.

Genin, S., and Boucher, C. 2004. Lessons learned from the genome analysis of Ralstonia solanacearum. Annu. Rev. Phytopathol. 42:107-134.

Golubov, A., Heesemann, J., and Rakin, A. 2003. Uncovering genomic differences in human pathogenic Yersinia enterocolitica. FEMS (Fed. Eur. Microbiol. Soc.) Immunol. Med. Microbiol. 38:107-111.

Guttman, D. S., Vinatzer, B. A., Sarkar, S. F., Ranall, M. V., Kettler, G., and Greenberg, J. T. 2002. A functional screen for the type III (Hrp) secretome of the plant pathogen Pseudomonas syringae. Science 295:1722-1726.

Hacker, J., and Kaper, J. B. 2000. Pathogenicity islands and the evolution of microbes. Annu. Rev. Microbiol. 54:641-679.

Harakava, R., and Gabriel, D. W. 2003. Genetic differences between two strains of Xylella fastidiosa revealed by suppression subtractive hybridization. Appl. Environ. Microbiol. 69:1315-1319.

Hibberd, A. M., Stall, R. E., and Bassett, M. J. 1987. Different phenotypes associated with incompatible races and resistance genes in bacterial spot disease of pepper. Plant Dis. 71:1075-1078.

Hoang, T. T., Karkhoff-Schweizer, R. R., Kutchma, A. J., and Schweizer, H. P. 1998. A broad host range FLP-FRT recombination system for sitespecific excision of chromosome located DNA sequences: Application for isolation of unmarked Pseudomonas aeruginosa mutants. Gene 212:77-86.

Horton, R. M., Hunt, H. D., Ho, S. N., Pullen, J. K., and Pease, L. R. 1989. Engineering hybrid genes without the use of restriction enzymes: Gene splicing by overlap extension. Gene 77:61-68.

Ignatov, A. N., Monakhos, G. F., Dzhalilov, F. S., and Pozmogova, G. V. 2003. Avirulence gene from Xanthomonas campestris pv. campestris homologous to the avrBs 2 locus is recognized in race-specific reaction by two different resistance genes in Brassicas. Russ. J. Genet.+ 38:1404-1410.

Jin, Q. L., and He, S. Y. 2001. Role of the Hrp pilus in type III protein secretion in Pseudomonas syringae. Science 294:2556-2558.

Jin, Q. L., Thilmony, R., Zwiesler-Vollick, J., and He, S. Y. 2003. Type III protein secretion in Pseudomonas syringae. Microb. Infect. 5:301-310.

Kamoun, S., and Kado, C. I. 1990. A plant-inducible gene of Xanthomonas campestris pv. campestris encodes an exocellular component required for growth in the host and hypersensitivity on nonhosts. J. Bacteriol. 172:5165-5172.

Kamoun, S., Kamdar, H. V., Tola, E., and Kado, C. I. 1992. Incompatible interactions between crucifers and Xanthomonas campestris involve a vascular hypersensitive response: Role of the hrpX locus. Mol. PlantMicrobe Interact. 5:22-33.

Kay, S., Boch J., and Bonas, U. 2005. Characterization of AvrBs3-Like effectors from a Brassicaceae pathogen reveals virulence and avirulence activities and a protein with a novel repeat architecture. Mol. PlantMicrobe Interact. 18:838-848.

Kearney, B., and Staskawicz, B. J. 1990. Widespread distribution and fitness contribution of Xanthomonas campestris avirulence gene avrBs2. Nature 346:385-386.

Kingsley, M. T., Gabriel, D. W., Marlow, G. C., and Roberts, P. D. 1993. The opsX locus of Xanthomonas campestris affects host range and biosynthesis of lipopolysaccharide and extracellular polysaccharide. J. Bacteriol. 175:5839-5850.

Lawrence, J. G., and Ochman, H. 1997. Amelioration of bacterial genomes: Rates of change and exchange. J. Mol. Evol. 4:383-397.
Lin, N. C., and Martin, G. B. 2005. An avrPto/avrPtoB mutant of Pseudomonas syringae pv. tomato DC3000 does not elicit Pto-mediated resistance and is less virulent on tomato. Mol. Plant-Microbe Interact. $18: 43-51$

Lorang, J. M., Shen, H., Kobayashi, D., Cooksey, D., and Keen, N. T. 1994. avrA and avrE in Pseudomonas syringae pv. tomato PT23 play a role in virulence on tomato plants. Mol. Plant-Microbe Interact. 7:508515.

Losada, L., Sussan, T., Pak, K., Zeyad, S., Rozenbaum, I., and Hutcheson, S. W. 2004. Identification of a novel Pseudomonas syringae Psy61 effector with virulence and avirulence functions by a HrpL-dependent promoter-trap assay. Mol. Plant-Microbe Interact. 17:254-262.

Maniatis, T., Fritsch, E. T., and Sambrook, J. 1982. Molecular Cloning: A Laboratory Manual. Cold Spring Harbor Laboratory Press, Cold Spring Harbor, NY, U.S.A.

Mukaihara, T., Tamura, N., Murata, Y., and Iwabuchi, M. 2004. Genetic screening of Hrp type III-related pathogenicity genes controlled by the $\mathrm{HrpB}$ transcriptional activator in Ralstonia solanacearum. Mol. Microbiol. 54:863-875.

Newman, K. L, Almeida, R. P., Purcell, A. H., and Lindow, S. E. 2003. Use of a green fluorescent strain for analysis of Xylella fastidiosa colonization of Vitis vinifera. Appl. Environ. Microbiol. 69:7319-7327.

Noel, L., Thieme, F., Nennstiel, D., and Bonas, U. 2002. Two novel type III-secreted proteins of Xanthomonas campestris pv. vesicatoria are encoded within the hrp pathogenicity island. J. Bacteriol. 184:1340-1348.

Nomura, K., and He, S. Y. 2005. Powerful screens for bacterial virulence proteins. Proc. Natl. Acad. Sci. U.S.A. 102:3527-3528.

O'Garro, L. W., Gibbs, H., and Newton, A. 1997. Mutation in the avrBs 1 avirulence gene of Xanthomonas campestris pv. vesicatoria influences survival of the bacterium in soil and detached leaf tissue Phytopathology 87:960-966.

Roden, J. A., Belt, B., Ross, J. B., Tachibana, T., Vargas, J., and Mudgett, M. B. 2004a. A genetic screen to isolate type III effectors translocated into pepper cells during Xanthomonas infection. Proc. Natl. Acad. Sci. U.S.A. 101:16624-16629.

Roden, J., Eardley, L., Hotson, A., Cao, Y., and Mudgett, M. B. 2004b. Characterization of the Xanthomonas AvrXv4 effector, a SUMO protease translocated into plant cells. Mol. Plant-Microbe Interact. 17:633643.

Rohmer, L., Guttman, D. S., and Dangl, J. L. 2004. Diverse evolutionary mechanisms shape the type III effector virulence factor repertoire in the plant pathogen Pseudomonas syringae. Genetics 167:1341-1360.

Rossier, O., Wengelnik, K., Hahn, K., and Bonas, U. 1999. The Xanthomonas Hrp type III system secretes proteins from plant and mammalian bacterial pathogens. Proc. Natl. Acad. Sci. U.S.A. 96:9368-9373.

Silhavy, T. J. 1997. Death by lethal injection. Science 278:1085-108.

Swarup, S., Defeyter, R., Brlansky, R. H., and Gabriel, D. W. 1991. A pathogenicity locus from Xanthomonas citri enables strains from several pathovars of Xanthomonas campestris to elicit canker-like lesions on citrus. Phytopathology 81:802-809.

Swarup, S., Yang, Y., Kingsley, M. K., and Gabriel, D. W. 1992. A Xanthomonas citri pathogenicity gene, pthA, pleiotropically encodes gratuitous avirulence on nonhost. Mol. Plant-Microbe Interact. 5:204-213.

Vicente, J. G., Conway, J., Roberts, S. J., and Taylor J. D. 2001. Identification and origin of Xanthomonas campestris pv. campestris races and related pathovars. Phytopathology 91:492-499.

Wichmann, G., and Bergelson, J. 2004. Effector genes of Xanthomonas axonopodis pv. vesicatoria promote transmission and enhance other fitness traits in the field. Genetics 166:693-706.

Yanisch-Perron, C., Vieira, J., and Messing, J. 1985. Improved M13 phage cloning vectors and host strains: Nucleotide sequences of the M13mp18 and pUC19 vectors. Gene 33:103-119.

Yang, Y., Yuan, Q., and Gabriel, D. W. 1996. Water soaking function(s) of $\mathrm{Xcm} \mathrm{H} 1005$ are redundantly encoded by members of the Xanthomonas avr/pth gene family. Mol. Plant-Microbe Interact. 5:204-213.

\section{AUTHOR-RECOMMENDED INTERNET RESOURCE}

Xanthomonas-ONSA FAPESP network: cancer.lbi.ic.unicamp.br/xanthomonas 